University of Rhode Island

DigitalCommons@URI

Open Access Master's Theses

1983

\title{
The Impact of Beltways Upon Selected Central City \\ Characteristics: A Social and Economic Indicator Analysis
}

Deborah M. Kupa

University of Rhode Island

Follow this and additional works at: https://digitalcommons.uri.edu/theses

\section{Recommended Citation}

Kupa, Deborah M., "The Impact of Beltways Upon Selected Central City Characteristics: A Social and Economic Indicator Analysis" (1983). Open Access Master's Theses. Paper 642.

https://digitalcommons.uri.edu/theses/642

This Thesis is brought to you for free and open access by DigitalCommons@URI. It has been accepted for inclusion in Open Access Master's Theses by an authorized administrator of DigitalCommons@URI. For more information, please contact digitalcommons-group@uri.edu. 


\section{THE IMPACT OF BELTWAYS}

UPON SELECTED CENTRAL CITY CHARACTERISTICS :

A SOCIAL AND ECONOMIC INDICATOR ANALYSIS

BY

DEBORAH M. KUPA

A THESIS PROJECT SUBMITTED IN PARTIAL FULFILLMENT

OF THE REQUIREMENTS FOR THE DEGREE OF

MASTER OF COMMUNITY PLANNING

AND

AREA DEVELOPMENT

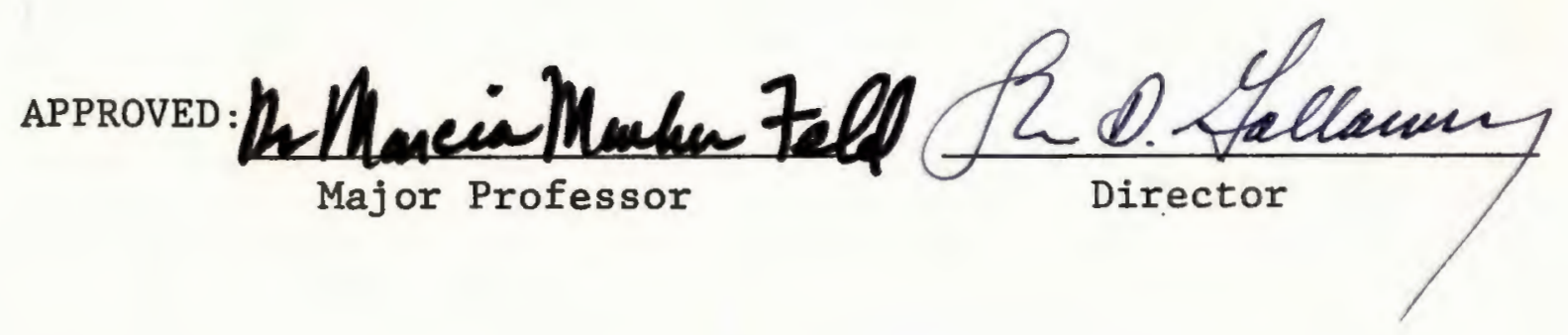

UNIVERSITY OF RHODE ISLAND

1983 
TABLE OF CONTENTS

ACKNOWLEDGEMENTS . . . . . . . . . . . . . ii

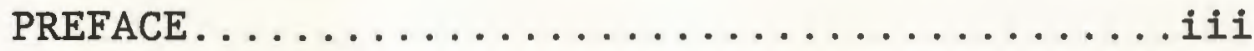

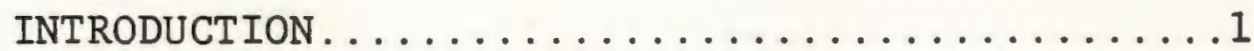

Chapter

I THE HISTORICAL PERSPECTIVE OF BELTWAYS

Introduction. ................ 5

Current Thought on Beltway Impacts......6 6

Summary.................... 10

II THE INDICATOR MODEL

Introduction. .................12

The Indicator Model..................13

Assumptions Inherent in the Indicator

Model......................... 14

The Rating system................... 15

Criteria for Indicator Selection. ....... 16

Interrelationships Between the

Indicators..................... 21

The Indicators within the Model.........36

III PROVIDENCE, RHODE ISLAND AND THE

ROUTE I-295 BELTWAY: A CASE STUDY

Introduction. . . . . . . . . . . . . . 42

History....................... 42

Key Elements in the City/Beltway

Development Process.............48

Summary..................... . 74

IV TESTING THE INDICATOR MODEL: THE ROUTE

I-295 CASE STUDY

Introduction. ..................78

Analysis of Beltway Impacts by

Area of Concern...............78

Demographics...............78

Employment................ 82

Housing. . . . . . . . . . . . . . . 84

Economic - Retail/Comercial......85

office.................... 86

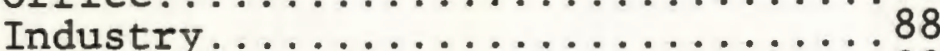

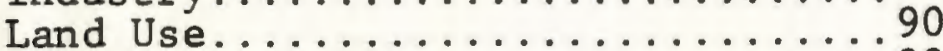

Transportation..............92

Summary....................... 
TABLE OF CONTENTS cont.

Chapter

V PROJECT CONCLUSIONS AND CRITIQUE.......97

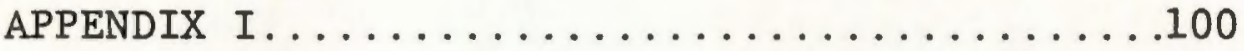

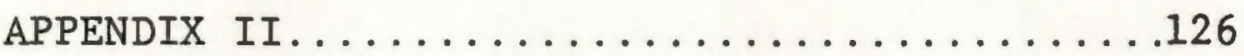

SOURCES . . . . . . . . . . . . . . . 128 


\section{LIST OF TABLES}

Table

I

II

III

IV

V

VI

VII

VIII

IX

$\mathrm{X}$

XI

XII

XIII

XIV

XV

XVI

XVII

XVIII

XIX

$\mathrm{XX}$

XXI

XXII

Indicators of Beltway Impact Upon

Central Cities..................17

Selected Indicators By Category:

Input Descriptive Indicators..........24

Purpose of Indicator Selection:

Input Descriptive Indicators.........25

Selected Indicators by Category:

Non-manipulable input indicators......26

Purpose of Indicator Selection:

Non-manipulable input indicators.......27

Selected Indicators by Category:

Analytic Indicators...............28

Purpose of Indicator Selection:

Analytic Indicators................29

Selected Indicators by Category:

Output descriptive indicators........30

Purpose of Indicator Selection:

Output Descriptive Indicators..........31

Selected Indicators by Category:

Side Effect Descriptive Indicators......34

Purpose of Indicator Selection:

Side Effect Descriptive Indicators......35

A List of the Rhode Island Towns

Nearest to Route I-295............45

Plant Additions, New Buildings, and

New Plants in Corridor Towns and

Providence, 1955 - 1958...........47

Change in Providence Population.......449

Population Trends of the Corridor

Towns ........................ . 50

Industry of Employed Persons.........52

Employment Trends by Industry for the I-295 Corridor Region, 1960-80......55

Trends in the Labor Force of the

Corridor Region, 1960-80...........55

Trend in the Range of Median Family

Income in the Corridor Towns........56

Trend in Residential Building Permits in Providence and Corridor Towns......58

Number of Single and Multi-family

Homes in Providence and the Corridor

Region, 1970,1980..............58

Regional Shopping Centers Built

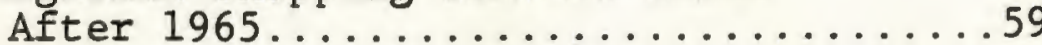




\section{LIST OF TABLES cont.}

Table

XXIII New Commercial Construction in Providence and the Corridor, 1966-1980.........66 62

XXIV New Construction for Manufacturers

in Providence and the Corridor Region.....65

XXV Land Uses in the City of Providence......67

XXVI Land Uses in the Corridor Region.........68

XXVII Average Daily Traffic on Route I-295.....73

\section{LIST OF FIGURES}

Figure

I Interrelationships in the Indicator Mode1..22

II Interstate Highways Recommended for

III

Accelerated Construction.............. 44

IV

Locations of the Regional Malis.........61

$\mathrm{V}$

Land Zoned for Industrial Use, $1977 \ldots . .663$

VI

Rhode Island Highway System...........70

Rhode Island Travel Times............. 72 


\section{ACKNOWLEDGEMENTS}

There are a number of people who have put considerable time and effort in bringing this project to a successful completion. First, I wish to express my sincere appreciation to Dr. Marcia M. Feld for her advice and enthusiasm on this project, and throughout my years in the department. She has brought a unique sense of humor, and unfailing support to every project I have attempted.

I would also like to thank Dr. Thomas D. Galloway for his comments and help in refining this paper. Dr. Galloway has provided a good working atmosphere in all the studies on which I have worked.

My parents, John and Brenda Kupa, have been a fine support team, in every sense of the word. I wish to thank them for providing me with an education and the chance to go my own way in every endeavor. 


\section{PREFACE}

The focus of this research project is on the development and testing of a methodology to assess the impacts of a beltway upon the central city it surrounds.

The analytic method employed in this study is social and economic indicator analysis. It is intended to provide the evaluator of highway impacts with a framework through which specific cases can be applied. The information system which is developed can then be employed in making policy decisions concerning the highway's impact upon its central city.

The methodology used in the project is tested through an application to a specific beltway and the city it surrounds. The conclusions derived from this test illustrate the ability of the methodology to present a valid examination of the specific case.

The key element within this study is the development of a normative methodology, which is not limited to strict quantitative data analysis, or simple qualitative review. The methodology intermixes these forms of analysis, and allows the decision-maker to consider the entire situation, including city policies. 


\section{INTRODUCTION}

The purpose of this research project is to develop and test a methodology for use in the assessment of the impacts that beltways have upon the central cities they surround. The methodology which is employed is social and economic indicator analysis, and the test is an application of the model to a specific beltway case.

The project is divided into five chapters. The information presented in Chapter I provides an encapsulation of historical and current literature on the impacts of beltways. The general intention of this chapter is to acquaint the reader with the internal issues of beltway impacts.

The second chapter presents the methodological framework through which the indicator model is developed. The model is derived from a number of sources, including the Land and Spilerman study entitled Social Indicator Models, and the United States Department of Transportation's The Land Use and Urban Development Impacts of Beltways. ${ }^{1}$ A number of functional areas are examined in Chapter II, including demographics; housing; employment; economics, with the sub-areas of retail/commercial, office, and manufacturing; land use and transportation. Indicators of a beltway's impact upon the central city were derived within each each functional area. In addition, there 
is an examination of the techniques employed in indicator selection, the assumptions inherent in the model, the interrelationships between the indicators, and the rating system used to determine the type of impact the beltway has had upon the central city.

Chapter III is a presentation of information through which the model is tested. The beltway chosen for model application is Interstate Route 295 (I-295) which surrounds the city of Providence, Rhode Island. The data is divided into the six functional areas described above, and is presented in both tabular and textual forms.

Chapter IV includes the application of the model to the I-295 case, and presents a number of conclusions as to the impacts of the beltway upon Providence. This is the test of the methodology which shows the ability of the model to manage information.

Chapter V presents the project conclusions, including an assessment of the indicator model as an appropriate methodological tool for use in determining beltway impacts. A brief discussion of further studies is provided, with consideration of the indicator model as an information system. In addition, the results of the development and testing of the model are critiqued and recommendations as to its improvement are made.

The intention of the study is to develop and test a specific method of impact assessment, social indica- 
tor analysis. In the planning process, it would represent the first stage in decision-making, that of information collection and analysis. Further stages of the process include examination of alternatives and the refinement of data analysis. 
FOOTNOTES

1. The extent to which these sources were used in the development of the methodology and indicators is described in Chapter II, The Indicator Model. 
CHAPTER I

THE HISTORICAL PERSPECTIVE OF BELTWAY IMPACTS

Introduction

The implementation of the Interstate Highway System in 1944 formed the basis for construction of many existing beltways, although at that time emphasis was placed upon building roads which penetrated the city centers. The Federal-Aid Highway Act of 1944 provided the funding for highway construction projects, including 2,300 miles of urban circumferential routes. ${ }^{1}$ As urban expressway projects progressed, funds were quickly depleted. The 1956 Federal-Highway Act provided the impetus for further highway construction. It was at this point that a requirement was initiated which held that "state highway departments, in planning a Federal-Aid project involving the bypassing of or going through a city or town, must hold, or offer to hold a public hearing and must consider the economic effects of such a location." 2

There have been approximately 40 beltways partially or completely constructed since 1956. The beltway examined in this study was originally built as part of the Interstate Highway System.

Subsequent Federal-Aid Highway Acts addressed the issue of transportation planning, with the approach shifting from a highway orientation to a multi-modal approach. ${ }^{3}$ It was not until the 1960's however, that transportation 
planning began to address the issues of land use planning, and the socio-economic, enviromental and energy impacts of highways. In the discussion of beltway impacts, concern was often expressed over the affects such roadways had upon the central cities they surrounded. Numerous studies have addressed this point, two of which are included in Appendix I.

Current Thought on Beltway Impacts

The relationships between beltway construction and the impacts of the highway have been explored in a somewhat limited manner. Studies range from a 1958 examination of the Route 128 corridor in Massachusetts to the 1980 U. S. Department of Transportation publication in which the federal policy implications of beltway construction were reviewed in a case study context.

Early impact studies concentrated on the positive effects beltways had upon the cities they served. Subsequent studies agree that the highways have some impact on urban growth and development patterns, but that these impacts were widely varied and were of differing magnitudes. The current area of study is concerned with whether beltways affect intrametropolitan growth patterns, especially the shift of population from the central city to outer suburban areas.

The majority of beltway impact studies indicate that the effects of such a roadway appear to vary with the type of city it surrounds. There are, however, some general 
attributes which are generalizable for most beltways. First, the construction of a beltway around a central city can improve the accessibility of the outer regions of a metropolitan area. In turn, this often triggers heightened residential, retail and industrial locations, especially at the interchanges of the beltway. Increased accessibility allows workers in the city to live further from their jobs without increasing work trip times, and allows firms to locate in lower cost sites distant from the city without losing contact with the metropolitan market. ${ }^{4}$ Although the positive aspects of increased regional accessibility are appealing to many firms, most of the current literature on locational decisions indicates that it is not sufficient to attract a large number of commercial and industrial establishments to beltway corridors. 5 There are a substantial number of elements other than accessibility which play key roles in attracting firms to the beltway corridor. These elements include the area's market potential in comparison to the city's market potential, the availability of utilities, current land use patterns, the availability of suitably zoned land for a variety of uses, along with a number of others. The literature recognizes that the construction of a beltway is not enough to create a market in an area that has few amenities, or which serves no existing market. 
Second, the effect of beltway construction upon a central city's economy, although varying widely, may often be negative. This is an impact which is thought to be highly dependent on the permissiveness of land use policies, and illustrates the importance of strong regional land use planning in a beltway area. Historically, central cities surrounded by surburban beltways showed lower gains in retail sales and employment than those cities without beltways. ${ }^{6}$

In addition, negative shifts in the areas of wholesaling and service sector employment, along with industrial employment were often present in beltway cities. ${ }^{7}$ These shifts tended to be small, but statistically significant.

In the area of study concerning development patterns, the majority of beltway impact studies indicate that any suburbanization which has taken place since the construction of the highway probably would have occurred in the absence of the construction. ${ }^{8}$ In addition, it is believed that beltways do not tend to change development patterns, but simply reinforce the patterns currently in existence. In a study examining several existing beltway's effects on development the pattern of a short-lived shift of office space construction to beltway sites and a clustering of garden apartments adjacent to the highway was evident. ${ }^{9}$ Impacts on other types of development were weak or non-existent. ${ }^{10}$ The conclusion of studies such as this one shows that while beltway construction can spear development in growth areas, it cannot change the development patterns in an area which does not have a market potential. ${ }^{11}$ 
In addition to the positive and neutral effects that beltway construction may have upon a central city and its suburbs, negative effects have been documented in many reports. Besides those negative points which have been discussed previously in this chapter, there are environmental and social issues which have been negatively affected by beltway construction. First, beltway travel is often not an energy efficient mode of transportation. Vehicle miles traveled usually increase in beltway areas, and public transit is less of a factor in transporting city commuters. These elements can lead to increased energy usage and less efficient use of a city's public transit program. There are, however, many methods to mitigate these effects, including encouraging nodal development along the highway, and the construction of park and ride facilities for city commuters in the beltway corridor.

The social impacts of beltway construction are as wideranging as the types of cities around which the highways are located. First, as a beltway can facilitate suburbanization of population and employment, few benefits are conferred upon lower income residents of the central city. ${ }^{12}$ The investments a city may make in the construction of a beltway may, in fact, affect the city's ability to provide needed social services. ${ }^{13}$ Lastly, job opportunities for central city residents may be reduced if development is attracted to the beltway area. 14 
Summary

The impacts of a beltway on the central city it surrounds are generally dependent on the type of city, the current growth patterns of the city, and the market potential of the beltway area. Although the effects outlined in this section can be viewed as general impacts of the majority of beltways, each highway should be viewed as a unique entity. The current literature addressing beltway development and impacts shows a large number of variables which must be considered when planning and assessing beltway construction. This study will attempt to develop and test a methodology for organizing this large information system through social indicator analysis. 
FOOTNOTES

1. U.S. Department of Transportation, The Land Use and Urban Development Impacts of Beltways - Final Report, (Washington, D.C.: U.S. Government Printing Office, 1980), p. 13 .

2. 70 U.S. Stat. 374.

3. U.S. Department of Transportation, p. 15.

4. U.S. Department of Transportation, The Land Use and Urban Development Impacts of Beltways - Summary. (Washington, D.C.: U.S. Government Printing Office, 1980), p. 15 .

5. The current literature, however, strongly supports the decentralization of households and firms due to the Interstate Highway System as a whole. Beltways comprise only a small percentage of the highway system, and are viewed in a different context than the highway system as a whole.

6. U.S. Department of Transportation, The Land Use and Urban Development Impacts of Beltways - Summary, P. 11.

7. Ibid., p. 12 .

8. Ibid., p. 13 .

9. Ibid., p. 11 .

10. Ibid.

11. Ibid.

12. Ibid.

13. Ibid., p. 15.

14. Ibid. 


\section{CHAPTER II}

\section{THE INDICATOR MODEL}

Introduction

For the purposes of this paper, the model is considered to be a hypothesis which addresses the relationships between a beltway and the central city it surrounds. It is a normative methodology which considers both quantitative information and qualitative analysis. The model employs social and economic indicators which are defined as statistical measures of social and economic conditions, past and present, measurable in a time series, within a specific geographical area. ${ }^{1}$ The geographical regions which are employed in this study are cities, towns and states. The corridor region is a compilation of a number of towns, and is calculated as the sum of those towns. Units of measure should be as specific as possible for use within the model, and should be easily compared.

Within the geographical areas, the following specific functional areas were selected for use in the model:

-Demographics

-Employment

-Housing

-Economics

-Retail/Commercial

-Office

-Industry

-Land Use

-Transportation 
The model relies upon the comparison of functional areas within the city to those areas within the corridor.

The indicators presented in this chapter were developed in part, from a review of current literature on beltway impacts. Two summaries of such literature, and the various measures used to assess these impacts, are found in Appendix I. The criteria for selection of indicators is presented at a later point in this chapter.

In addition, the indicators are organized into a framework illustrating their specific interrelationships. This framework is loosely based upon the social indicator model developed in the Land and Spilerman study entitled Social Indicator Models. ${ }^{2}$

The chapter also includes a discussion of the assumptions inherent in the model, and the rating system through which the impacts of the beltway upon the city are assessed. An explanation of each indicator and its purposes within the model is also included.

\section{The Indicator Model}

The basic premise underlying the indicator model in this study is the assumption that there is a quantifiable relationship between a beltway and the functional area characteristics of the city it surrounds. The model provides a structure for illustrating these impacts through its interrelationships and through the rating system. A list of the indicators employed in the model 
are found in Table $I$.

Assumptions Inherent in the Indicator Mode1

There are five primary assumptions which form the boundaries for use of the indicator model in this study. The major assumption used in the model is the ability of a beltway to have a measurable effect on the various functional area characteristics of the city it surrounds. This assumption is tested in the application presented in Chapter IV. It is dependent upon the units of measure, the type of data employed (primary or secondary), the interrelationships between indicators, and the validity of the rating system.

The second assumption made in the model design is that the level of aggregation of measures provides a reliable picture of beltway impacts. Current social indicator literature states that this is a valid assumption. ${ }^{3}$ Because the model is designed for use in the early stages of the planning process, further use should result in a refinement of the data, and of the analysis itself.

As a result of time constraints, the bulk of the information collected for the testing of this model is of a secondary nature. The United States Census is the predominant source of data for the model application. A continuation of this model application in the planning process would require the use of primary data. 
The fourth assumption made in this methodology lies in the rating system. Because of the normative nature of social and economic indicator analysis, there is a connection between the quantitative information and the qualitative conclusions. The rating system is described in the following section.

\section{The Rating System}

A principal element of the indicator model is the rating of beltway impacts. This system is founded upon the city's normative policy comittments. That is, whether an impact is rated as positive, neutral or negative depends on the contextual base from which the city's decisions are made. For example, it increased industrial development is one of a city's policy objectives, then additional construction of industrial plants in the city is viewed as a positive occurrence. The positive, neutral and negative ratings are described in detail below.

Positive Impact - This rating indicates the beltway has benefitted a selected functional area within the city, and follows its stated policy direction. This ranges from the improvement of the accessibility to the city's shopping areas to attracting additional office space to the central city. 
Neutral Impact - A neutral rating means the construction of a beltway has had no significant impact (benefit or detriment) on a particular functional area within the city. An example would be an impact which cannot be assigned to beltway development because the major forces behind the impact lie elsewhere.

Negative Impact - This rating indicates the beltway has had a detrimental affect upon a certain functional area within the city. For example, if city policy aimed toward revitalizing the central business district in terms of additional retail and commercial establishments, and the beltway was attracting most new retail and commercial development to its corridor towns, a negative impact would be assigned.

Criteria for Indicator Selection

The indicators which were chosen for use within the model are found in Table I. They were selected by employing the following criteria:

1. Study relevance - The chosen measure must be applicable to the problem being reviewed, in this case the effects of beltway construction on macroscale central city characteristics.

2. Reliability - The quality of the measure that consistently reflects a characteristic without wide variability. ${ }^{4}$ 
TABLE I

INDICATORS OF BELTWAY IMPACT

UPON CENTRAL CITIES

\begin{tabular}{|c|c|}
\hline $\begin{array}{l}\text { Area of } \\
\text { Concern }\end{array}$ & Indicator \\
\hline Demographics & $\begin{array}{l}\text { City population trends. } \\
\text { SMSA/County/Corridor population } \\
\text { trends. } \\
\text { Nonwhite City population trends. }\end{array}$ \\
\hline Employment & $\begin{array}{l}\text { Trend in City employment by in- } \\
\text { dustry class. } \\
\text { Trend in SMSA/County/Corridor } \\
\text { employment by industry class. } \\
\text { Unemployment rate in the City } \\
\text { before and after beltway cons- } \\
\text { truction. } \\
\text { Median family income in City. } \\
\text { Median family income in SMSA/ } \\
\text { County/Corridor. }\end{array}$ \\
\hline Housing & $\begin{array}{l}\text { Total single and multi-family } \\
\text { dwelling units in City/SMSA/ } \\
\text { County/Corridor. } \\
\text { Trend in residential building } \\
\text { permits in City/County/SMSA/ } \\
\text { Corridor. }\end{array}$ \\
\hline $\begin{array}{l}\text { Economic: } \\
\text { Retail/Com- } \\
\text { mercial }\end{array}$ & $\begin{array}{l}\text { Trend in location of regional } \\
\text { shopping centers before and af- } \\
\text { ter beltway construction. } \\
\text { New commercial construction in } \\
\text { the City after beltway construc- } \\
\text { tion. } \\
\text { New commercial construction in } \\
\text { the SMSA/County/Corridor after } \\
\text { beltway construction. }\end{array}$ \\
\hline
\end{tabular}


TABLE I cont.

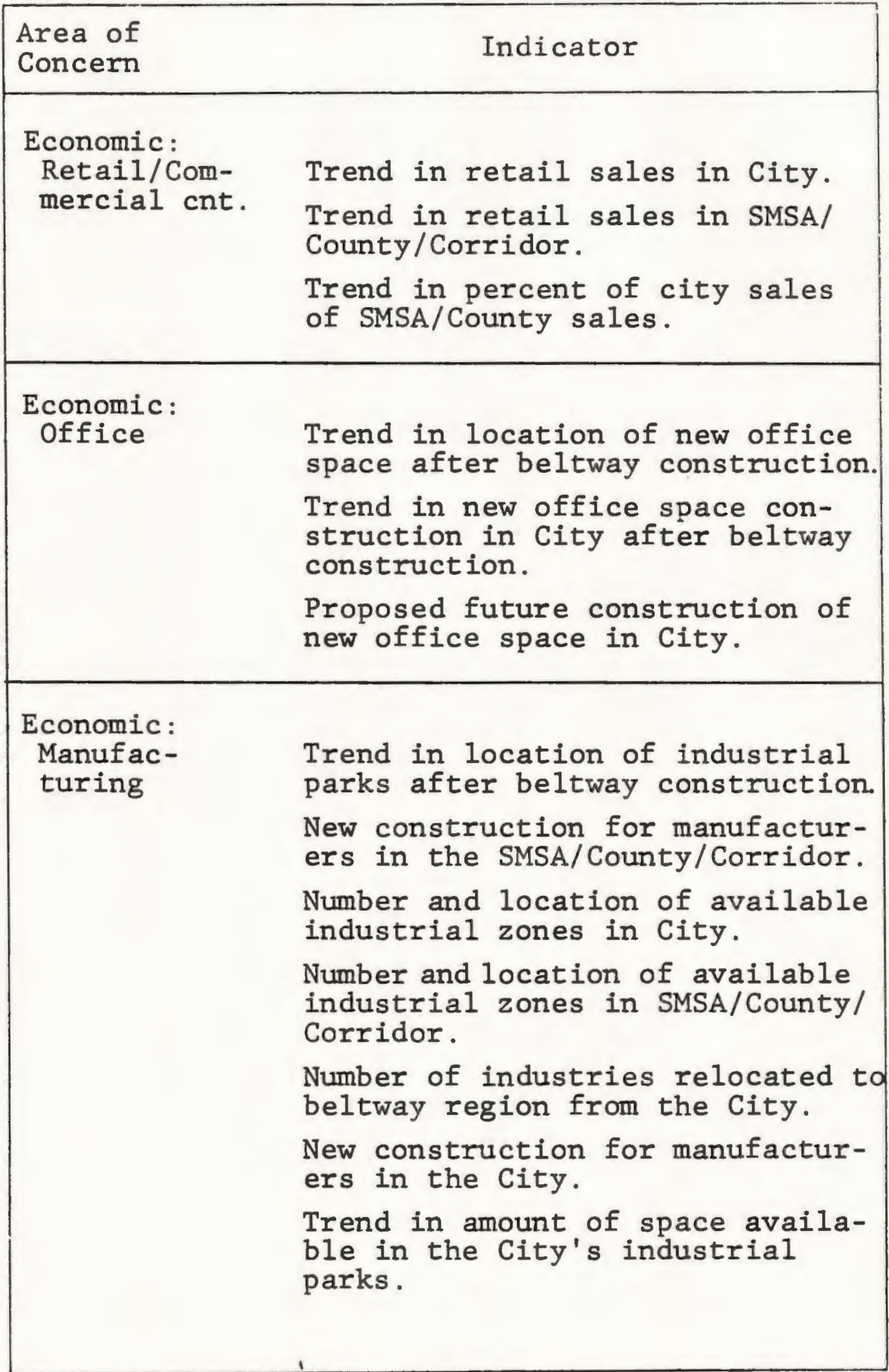


TABLE I cont.

\begin{tabular}{|c|c|}
\hline $\begin{array}{l}\text { Area of } \\
\text { Concern }\end{array}$ & Indicator \\
\hline \multirow{2}{*}{$\begin{array}{l}\text { Economic: } \\
\text { Manufac- } \\
\text { turing } \\
\text { Cont. }\end{array}$} & $\begin{array}{l}\text { Availability of utilities in the } \\
\text { SMSA/County/Corridor. }\end{array}$ \\
\hline & $\begin{array}{l}\text { Availability of utilities in the } \\
\text { City. }\end{array}$ \\
\hline \multirow[t]{9}{*}{ Land Use } & $\begin{array}{l}\text { Trend in land uses in the City } \\
\text { before and after beltway cons- } \\
\text { truction. }\end{array}$ \\
\hline & $\begin{array}{l}\text { Current land uses in the City/ } \\
\text { SMSA/County/Corridor. }\end{array}$ \\
\hline & $\begin{array}{l}\text { Amount of developable space in } \\
\text { City. }\end{array}$ \\
\hline & $\begin{array}{l}\text { Amount of developable space in } \\
\text { SMSA/County/Corridor. }\end{array}$ \\
\hline & $\begin{array}{l}\text { Number, location and type of } \\
\text { physical constraints on develop- } \\
\text { ment. }\end{array}$ \\
\hline & $\begin{array}{l}\text { Trend in location of residential, } \\
\text { commercial and industrial uses } \\
\text { before and after beltway cons- } \\
\text { truction. }\end{array}$ \\
\hline & $\begin{array}{l}\text { Average cost of land per square } \\
\text { foot in City. }\end{array}$ \\
\hline & $\begin{array}{l}\text { Average cost of land per square } \\
\text { foot in Corridor. }\end{array}$ \\
\hline & $\begin{array}{l}\text { Size of central city in square } \\
\text { miles. }\end{array}$ \\
\hline \multirow[t]{2}{*}{ Transportation } & $\begin{array}{l}\text { Average daily traffic on beltway } \\
\text { over time. }\end{array}$ \\
\hline & $\begin{array}{l}\text { Number of interchanges on belt- } \\
\text { way. }\end{array}$ \\
\hline
\end{tabular}


TABLE I cont.

Area of

Concern

Indicator

Transportation Spacing of interchanges on beltway.

Extensiveness of radial highway system from central city.

Length of beltway in miles.

Number of automobiles available per family in City/Beltway region. Years of beltway construction. Average number of miles the beltway is located from the city center.

Proximity of beltway to alternate modes of transportation. 
3. Validity - The extent to which the measure reflects the concept that it is intended to measure. Three basic approaches are normally used to test for indicator validity. 5

a. Examine the design of the measure and decide if the measure is a reasonable one. This is a relatively subjective test, relying on intuition and knowledge of the concept/problem the indicator is intended to measure.

b. Examine the measure to see if it behaves the way it is expected to behave.

c. Look at the behavior of other measures of the same or related phenomena.

4. Availability - The data should be readily available through standard collection methods.

5. Timeliness - All measures should be time-relevent and trends should relate to the correct time period.

6. Aggregation - A specific level of aggregation, macroscale or microscale, should be designated for ease of comparison.

Interrelationships Between the Indicators

In order to illustrate the interrelationships of the indicators within the model, they are organized into the framework in Figure I. ${ }^{6}$ Five main types of indicators are identified within the flow chart, and are defined as follows: ${ }^{7}$ 


\section{-

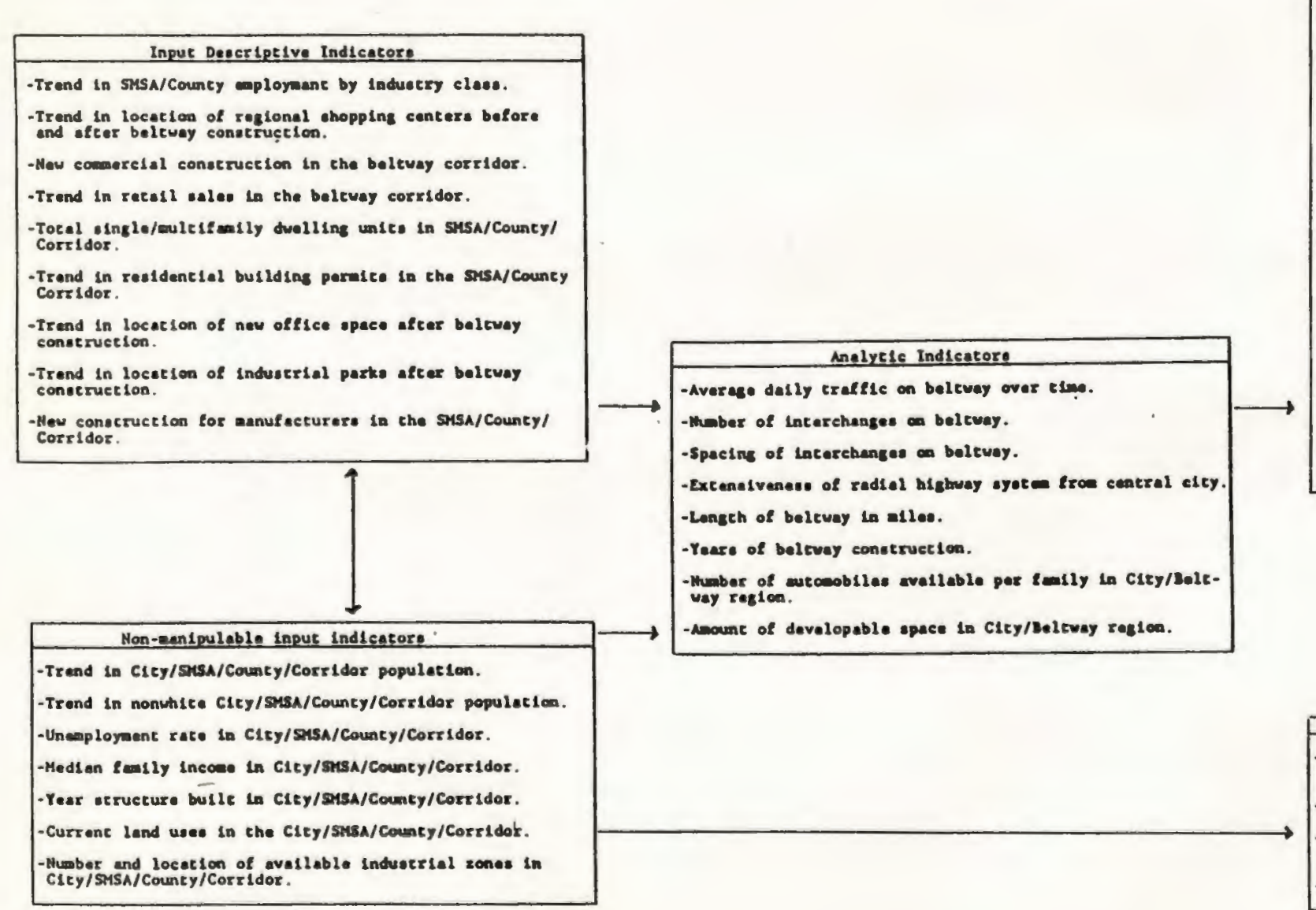

Output Descriptive Indlactoro - Irend in Cicy aployent by Induatry nector. - Mor comenctel construetion in the Cley over tian. -Trend in recall seles in Cley. -Pescent of Clcy', share of cotel SHSA retell ecler over cices.

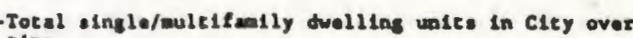

-Trend in resideatisl bullding peralte in cley. Trend in nou offlee opece conatruetion in ciey. - Proponed future construection of now offlce developeme -Mubar of Induatries relocated to beltuay reglion troe

- Irend to mount of apace avallable in the city' Induscrisel parko. - Heu conectuction for annufacturers in Cicy. -Trand in land usee in the C1Cy batore and after beltway

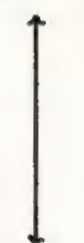

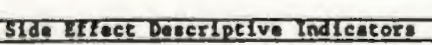
Average number of allog the beltway lo located froe

size of central city in squere allee.

-Averase coet of land par squere foot in Cley/Delevay reglons.

Avellabllity of utillties In Eolevey roulon and cley. 
1. Input descriptive indicators are those which represent conditions in the beltway region, whether Standard Metropolitan Statistical Area, county or corridor which can be manipulated by decision makers.

2. Non-manipulable descriptive indicators represent city or belt region conditions which cannot be altered by decision-makers .

3. Output descriptive indicators define the city conditions resulting from the impacts of the beltway on the central city.

4. Side-effect descriptive indicators are those variables which influence, or are influenced by the conditions and processes being considered.

5. Analytic indicators measure the underlying relationships which affect the output indicators, both descriptive and side-effect.

For example, the number of multifamily units built in the corridor, a variable which can be changed by policy makers, is related to the number of such units built (or not built) in the city, as a result of beltway construction. Non-manipulable indicators which would effect this are total city and regional population, and the side-effect indicator is the average cost of land per square feet in the city and beltway region. 


\section{TABLE II \\ SELECTED INDICATORS BY CATEGORY}

$(1960,1970,1980)$

\section{Input Descriptive Indicators}

-Trend in SMSA/County employment by industry class.

-Trend in location of regional shopping centers before and after beltway construction.

-New commercial construction in the beltway corridor.

-Trend in retail sales in the beltway corridor.

-Total single/multifamily dwelling units in SMSA/County/ Corridor.

-Trend in residential building permits in the SMSA/County Corridor.

-Trend in location of new office space after beltway construction.

-Trend in location of industrial parks after beltway construction.

-New construction for manufacturers in the SMSA/County/ Corridor. 
TABLE III

\section{PURPOSE OF INDICATOR SELECTION}

(Input Descriptive Indicators)

\begin{tabular}{|c|c|}
\hline Indicator & Purpose \\
\hline $\begin{array}{l}\text { - Trend in SMSA/County/Corridor employ- } \\
\text { ment by industry class. } \\
\text { - Trend in location of regional shop- } \\
\text { ping centers before and after belt- } \\
\text { way construction. }\end{array}$ & $\begin{array}{l}\text { Measure stability/change in employment } \\
\text { over time. } \\
\text { Trace the induced commercial development } \\
\text { in the highway corridor. }\end{array}$ \\
\hline $\begin{array}{l}\text {-New commercial construction in the } \\
\text { highway corridor. }\end{array}$ & $\begin{array}{l}\text { Trace the induced commercial development } \\
\text { in the highway corridor. }\end{array}$ \\
\hline $\begin{array}{l}\text { - Trend in retail sales in the highway } \\
\text { corridor. }\end{array}$ & Assess the direction of retail trade. \\
\hline $\begin{array}{l}\text {-Total single/multifamily dwelling } \\
\text { units in SMSA/County/Corxidor. }\end{array}$ & $\begin{array}{l}\text { Measure the induced housing development } \\
\text { in the highway corridor. Assess patterns } \\
\text { of suburbanization. }\end{array}$ \\
\hline -Trend in residential building permits. & $\begin{array}{l}\text { Measure the induced housing development } \\
\text { in the highway corridor. Assess patterns } \\
\text { of suburbanization. }\end{array}$ \\
\hline $\begin{array}{l}\text { - Trend in location of new office } \\
\text { space after beltway construction. }\end{array}$ & $\begin{array}{l}\text { Measure the induced office space develop- } \\
\text { ment in the highway corridor. }\end{array}$ \\
\hline $\begin{array}{l}\text {-Trend in location of industrial parks } \\
\text { after beltway construction. }\end{array}$ & $\begin{array}{l}\text { Measure the induced industrial develop- } \\
\text { ment in the highway corridor. }\end{array}$ \\
\hline $\begin{array}{l}\text {-New construction for manufacturers in } \\
\text { SMSA/County/Corridor. }\end{array}$ & $\begin{array}{l}\text { Measure the induced industrial develop- } \\
\text { ment in the highway corridor. }\end{array}$ \\
\hline
\end{tabular}




\section{TABLE IV \\ SELECTED INDICATORS BY CATEGORY}

$(1960,1970,1980)$

\begin{tabular}{|l|}
\hline Non-manipulable input indicators \\
\hline -Trend in City/SMSA/County/Corridor population. \\
-Trend in nonwhite City/SMSA/County/Corridor population. \\
-Unemployment rate in City/SMSA/County/Corridor. \\
-Median family income in City/SMSA/County/Corridor. \\
-Year structure built in City/SMSA/County/Corridor. \\
-Current land uses in the City/SMSA/County/Corridor. \\
-Number and location of available industrial zones in \\
City/SMSA/County/Corridor.
\end{tabular}


TABLE $V$

PURPOSE OF INDICATOR SELECTION

(Non-manipulable input indicators)

\begin{tabular}{|c|c|}
\hline Indicator & Purpose \\
\hline $\begin{array}{l}\text {-Trend in City/SMSA/County/Corridor } \\
\text { population. }\end{array}$ & $\begin{array}{l}\text { Assess growth trends and suburbanization } \\
\text { patterns. }\end{array}$ \\
\hline $\begin{array}{l}\text {-Trend in nonwhite City/SMSA/County/ } \\
\text { Corridor population. }\end{array}$ & $\begin{array}{l}\text { Trace any segregation effects beltway } \\
\text { construction may have had. }\end{array}$ \\
\hline $\begin{array}{l}\text {-Unemployment rate in City/SMSA/ } \\
\text { County/Corridor. }\end{array}$ & Measure of economic stability. \\
\hline $\begin{array}{l}\text {-Median family income in City/SMSA/ } \\
\text { County/Corridor. }\end{array}$ & $\begin{array}{l}\text { Assess the buying power differences in the } \\
\text { city/beltway regions. }\end{array}$ \\
\hline $\begin{array}{l}\text {-Year structure built in City/SMSA/ } \\
\text { County/Corridor. }\end{array}$ & $\begin{array}{l}\text { Assess overall quality of housing avail- } \\
\text { able in the city/beltway regions. }\end{array}$ \\
\hline $\begin{array}{l}\text { - Current land uses in the City/SMSA/ } \\
\text { County/Corridor. }\end{array}$ & $\begin{array}{l}\text { Provide a spatial profile of the city/ } \\
\text { beltway regions as they now exist. }\end{array}$ \\
\hline $\begin{array}{l}\text { - Number and location of available } \\
\text { industrial zones in the City/SMSA/ } \\
\text { County/Corridor. }\end{array}$ & $\begin{array}{l}\text { Assess the city/beltway area's ability } \\
\text { to provide suitable locations for indus- } \\
\text { trial development. }\end{array}$ \\
\hline
\end{tabular}


TABLE VI

SELECTED INDICATORS BY CATEGORY

$(1960,1970,1980)$

Analytic Indicators

-Average daily traffic on beltway over time.

- Number of interchanges on beltway.

-Spacing of interchanges on beltway.

-Extensiveness of radial highway system from central city.

-Length of beltway in miles.

-Years of beltway construction.

- Number of automobiles available per family in City/Beltway region.

-Amount of developable space in City/Beltway region. 
TABLE VII

PURPOSE OF INDICATOR SELECTION

(Analytic Indicators)

\begin{tabular}{|c|c|}
\hline Indicator & Purpose \\
\hline -Average daily traffic on beltway. & $\begin{array}{l}\text { Assess the changes in the extent to which } \\
\text { the beltway is used. }\end{array}$ \\
\hline -Number of interchanges on beltway. & $\begin{array}{l}\text { Measure the available prime developable } \\
\text { space in the beltway corridor. }\end{array}$ \\
\hline -Spacing of interchanges on beltway. & $\begin{array}{l}\text { Measure the available prime developable } \\
\text { space in the beltway corridor. }\end{array}$ \\
\hline $\begin{array}{l}\text {-Total amount of developable space in } \\
\text { City/Beltway region. }\end{array}$ & $\begin{array}{l}\text { Measure the available prime developable } \\
\text { space in the beltway corridor. }\end{array}$ \\
\hline $\begin{array}{l}\text {-Extensiveness of radial highway system } \\
\text { from central City. }\end{array}$ & $\begin{array}{l}\text { Assess the availability of other transpor- } \\
\text { tation systems in the region. }\end{array}$ \\
\hline -Length of beltway in miles. & $\begin{array}{l}\text { Measure the total space on which develop- } \\
\text { ment may occur. }\end{array}$ \\
\hline -Years of beltway construction. & $\begin{array}{l}\text { Trace the time period in which the beltway } \\
\text { was planned and built. }\end{array}$ \\
\hline $\begin{array}{l}\text {-Number of automobiles available per } \\
\text { family in City/Beltway region. }\end{array}$ & $\begin{array}{l}\text { Gauge the ability of residents to utilize } \\
\text { the beltway. }\end{array}$ \\
\hline
\end{tabular}




\section{TABLE VIII}

\section{SELECTED INDICATORS BY CATEGORY}

$$
\text { (1960, 1970, 1980) }
$$

Output Descriptive Indicators
-Trend in City employment by industry sector.
-New commercial construction in the City over time.
-Trend in retail sales in City.
- Percent of City's share of total SMSA retail sales over
time.
-Total single/multifamily dwelling units in City over
time.
-Trend in residential building permits in City.
-Trend in new office space construction in City.
- Proposed future construction of new office development
in City.
-Number of industries relocated to beltway region from
the City.
-Trend in amount of space available in the City's indus-
trial parks.
-New construction for manufacturers in City.
- Trend in land uses in the City before and after beltway
construction.


TABLE IX

PURPOSE OF INDICATOR SELECTION

(Output Descriptive Indicators)

\begin{tabular}{|c|c|}
\hline Indicator & Purpose \\
\hline $\begin{array}{l}\text {-Trend in City employment by industry } \\
\text { sector. }\end{array}$ & $\begin{array}{l}\text { Measure the stability/changes in employment } \\
\text { to form a profile of city's development } \\
\text { directions. }\end{array}$ \\
\hline $\begin{array}{l}\text {-New commercial construction in the } \\
\text { City over time. }\end{array}$ & $\begin{array}{l}\text { Assess the commercial development in the } \\
\text { city to compare with beltway region. }\end{array}$ \\
\hline -Trend in retail sales in City. & $\begin{array}{l}\text { Assess the direction of retail trade down- } \\
\text { town for comparison with beltway. }\end{array}$ \\
\hline $\begin{array}{l}\text { - Percent of City's share of total SMSA } \\
\text { retail sales over time. }\end{array}$ & $\begin{array}{l}\text { Assess the direction of retail trade down- } \\
\text { town for comarison with beltway. }\end{array}$ \\
\hline $\begin{array}{l}\text {-Total single/multifamily dwelling units } \\
\text { in City over time. }\end{array}$ & $\begin{array}{l}\text { Trace the suburbanization patterns in the } \\
\text { city and form a profile of its housing. }\end{array}$ \\
\hline $\begin{array}{l}\text {-Trend in residential building permits } \\
\text { in the City. }\end{array}$ & $\begin{array}{l}\text { Trace the suburbanization patterns in the } \\
\text { city and form a profile of its housing. }\end{array}$ \\
\hline $\begin{array}{l}\text { - Trend in new office space construction } \\
\text { in the City. }\end{array}$ & $\begin{array}{l}\text { Assess the availability of office space in } \\
\text { the city and the direction of its growth } \\
\text { patterns. }\end{array}$ \\
\hline $\begin{array}{l}\text {-Proposed future construction of new } \\
\text { office development in the City. }\end{array}$ & $\begin{array}{l}\text { Assess the availability of office space in } \\
\text { the city and the direction of its growth } \\
\text { patterns. }\end{array}$ \\
\hline $\begin{array}{l}\text { - Number of industries relocated to } \\
\text { beltway region from the city. }\end{array}$ & $\begin{array}{l}\text { Measure the shift in industry locations } \\
\text { after beltway construction. }\end{array}$ \\
\hline
\end{tabular}


TABLE IX cont.

\section{PURPOSE OF INDICATOR SELECTION}

(Output Descriptive Indicators)

\begin{tabular}{|l|l|}
\hline \multicolumn{1}{|c|}{ Indicator } & Purpose \\
\hline $\begin{array}{l}\text {-Trend in amount of space available in } \\
\text { the City's industrial parks. }\end{array}$ & $\begin{array}{l}\text { Measure the shift in industry 1ocations } \\
\text { after beltway construction. }\end{array}$ \\
$\begin{array}{l}\text {-New construction for manufacturers } \\
\text { in the City. }\end{array}$ & $\begin{array}{l}\text { Measure the shift in industry 1ocations } \\
\text { after beltway construction. } \\
\text {-Trend in land uses in the City before } \\
\text { and after belt construction. }\end{array}$ \\
\hline
\end{tabular}




\section{TABLE X \\ SELECTED INDICATORS BY CATEGORY \\ $(1960,1970,1980)$}

Side Effect Descriptive Indicators

-Average number of miles the beltway is located from the city.

-Size of central city in square miles.

-Average cost of land per square foot in City/Beltway regions.

-Availability of utilities in Beltway region and City. 
TABLE XI

PURPOSE OF INDICATOR SELECTION

(Side Effect Descriptive Indicators)

\begin{tabular}{|c|l|}
\hline \multicolumn{1}{|c|}{ Indicator } & Purpose \\
\hline - Average number of miles beltway is & $\begin{array}{l}\text { Assess land area available for develop- } \\
\text { ment within the beltway. }\end{array}$ \\
$\begin{array}{l}\text {-Size of central City in square } \\
\text { miles. }\end{array}$ & $\begin{array}{l}\text { Compare to available land in suburbs } \\
\text { and beltway region. }\end{array}$ \\
$\begin{array}{l}\text {-Average cost of land per square } \\
\text { foot in City/Beltway regions. }\end{array}$ & $\begin{array}{l}\text { Assess differences in land values for } \\
\text { city and beltway regions. } \\
\text {-Availability of utilities in City/ } \\
\text { Beltway regions. }\end{array}$ \\
$\begin{array}{l}\text { Assess the current development capacity } \\
\text { of the available land in the city and } \\
\text { beltway regions. }\end{array}$ \\
\hline
\end{tabular}


The indicators presented in Table I are divided by type and purpose in Tables II to XI. A discussion of the context in which they are viewed within the model follows.

\section{The Indicators within the Model}

Demographic

The selected indicators in this functional area are descriptive trends of population for cities and the regions surrounding them. The primary function of the indicators is to illustrate any suburbanization effects that the beltway may have upon the city it surrounds. For example, if the population of a city decreases with a corresponding increase in beltway corridor population over time, it indicates the city may be losing population to the beltway corridor. It is important to remember, however, that this is only possible when the indicators are viewed in the context of the entire model and its interrelationships.

Employment

The trends in the number of corridor or other geographical area residents employed by industry sector are descriptive indicators, which can be somewhat influenced by beltway construction. They are important in assessing the types of firms being served by the corridor and city, in conjunction with the labor supply. The number of persons employed by industry category is used to compare the city mix 
with the regional mix, therefore assessing the differences between the areas. This enables the analyst to later assess any gross shifts of industry employment from the city to the beltway corridor.

The city unemployment rates before and after construction of the beltway are intended to describe any changes the road may have caused in city employment, when used along with the industry class shifts, and the number and location of industrial parks. It is somewhat of a hybrid mix of analytic and descriptive indicator types.

Lastly, the measure of median family income for city, SMSA and county residents is generally descriptive. It should follow the general statistical inference of higher family income in areas outside city boundaries, in most cases.

Housing

The trend in the years of structure construction is intended to illustrate the phenomena of suburbanization. In theory, the years that structures in the beltway corridor were built would be more recent than the majority of those in the central city. Beltways tend to attract some new housing development, although as stated in Chapter I, do not have as large an impact on the housing market as believed in the early literature. The main impact upon the city here is that new housing built in the beltway region will detract from the central city 
housing market. A second indicator which would aid in the determination of trends in city and corridor residential development is the number of building permits issued for each geographical area in a time series. This measure, in conjunction with the total number of single family homes per year in each area should provide a fairly accurate portrayal of the direction of residential development, that is, whether it is staying in the city or has moved to the beltway corridor towns.

The number of multifamily units constructed in the city and corridor region, in addition to the number of single family homes, illustrates the current and historical mix of housing types in each area. It also gives a sense of trends toward increased multifamily or single family housing construction.

\section{Economic - Retail/Conmercial}

The three main indicators in this category are the new commercial construction in the beltway and city areas over time, the number and location of regional shopping centers built after the beltway was completed, and the trend in retail sales for the belt and city regions. The impacts upon the central city shown by all of the above 
indicators tend to be somewhat negative. This is especially true if a strong central city revitalization movement does not exist. Regional shopping centers are often located at or near beltway interchanges, providing increased retail sales in the corridor region. The beltway interchanges often attract retail establishments away from the city, where access is poor, parking problems abound, and the potential market is less broad.

Office

The location and amount of office space, as well as proposed future development of office space in the city are the major indicators of beltway impact in this section. They are intended to show the movement of office development away from the central city to the beltway corridor, in addition to mitigation efforts by the city to attract additional office development to offset any losses.

\section{Industry}

The trends in location of industrial parks are intended to illustrate the attractive capacity of the beltway when the proper mixture of ingredients is present. Beltways attract industrial parks for a number of reasons: 1) accessibility, 2) the proximity of other modes of transportation, 3) the labor force mix, 4) the proximity of housing for employees, 5) the presence of utilities, and above all others, 6) usable, available, and spacious 
land. Therefore, all of the indicators selected for this section must be employed as an interrelated group to assess belt impacts.

\section{Land Use and Transportation}

The sixteen indicators included in these two sections are generally descriptive. They illustrate the availability and type of land available in the regions, the zoning requirements, and what types of access exist. In addition, the beltway can be described in fairly complete form through the transportation indicators. The number and spacing of interchanges are important elements for use with the economic section, especially in judging the locational decision. Again, interrelationships between these measures and the indicizors of other categories should be keenly observed for a clear assessment of belt impacts.

\section{Summary}

The indicators and the model of their interrelationships have been presented in this chapter. The indicators were based upon those measures used by beltway impact evaluators in the case summaries. The model is constructed through the employment of a social indicator model developed in Social Indicator Models. ${ }^{8}$ In addition, a number of new indicators were chosen through a selection process of specific criteria, and were assigned a positive, neutral or negative connotation as they related to the beltway's impact upon the functional area characteristics of the central city. 


\section{FOOTNOTES}

1. This definition of the term social indicator differs somewhat from the generally accepted definition. Social indicators are defined as normative statistics which measure changing conditions; they are used in a time series, or disaggregated by other characteristics; and they are theory based, goal-connected, and based on the assumption of predictability of group behavior. (Joanne Cassulo, "The United State Self-Determination Policy in Indian Affairs: An Indicator Systems Policy Analysis," Unpublished thesis, University of Rhode Island, 1982.) p. 28.

2. Kenneth C. Land, Social Indicator Models ed. Land and Spilerman (New York: Sage Foundation, 1975) p. 18. The Land and Spilerman model is a complex social system model intended to measure the outcomes of social programs. Elements of the model which are used inthis project are the interrelational aspects of the indicators, and a modification of the indicator classifications. For example, Land and Spilerman's policy instrument indicators. are modified to become input descriptive indicators in the present model. In addition, the meaning of the indicator is somewhat altered, and is presented in the body of the report.

3. Ibid. pp. 30-31. (The units of measure which are used in the application of this model to the Interstate Route 295 case are cities and towns, rather than the larger aggregation of SMSA or county. This is due to the need for a more refined level of analysis than the aggregate data is able to provide. In many of the examples in this chapter, however, the SMSA and county references are included to provide the analyst with a choice of measurement units.)

4. Judith deNeufville, Social Indicators and Public Policy. (Elsevier Scientific Publishing Company: New York, 1975), p. 144.

5. Ibid., pp. 63-64.

6. Land, p. 18.

7. Ibid.

8. Ibid. 
CHAPTER III

PROVIDENCE, RHODE ISLAND

AND THE ROUTE I-295 BELTWAY:

A CASE STUDY

Introduction

Planning for a circumferential highway around Providence, Rhode Island began in the early 1960's. It was a part of the Federal-Aid Highway program of the United States System of Interstate Highways enacted in 1956, as were many of the beltway constructed during that period. (See Chapter I)

The highway was constructed in part to solve the traffic congestion problems of Providence and Route I-95. In addition, economic development planners viewed the belt as a chance to repeat the success of Boston's Route 128 as a manufacturing, office and high technology center. ${ }^{1}$ The beltway's completion in 1975 has raised the question of whether it has met with success.

This chapter is intended to provide a review of Providence and its relationship with its beltway. The chapter is structured in a similar fashion as the four case summaries presented in Chapter II; the review is more comprehensive.

\section{History}

The 1959 study by Arthur D. Little, Inc. entitled 
"Industrial Development and Highway Planning in Rhode Island" recommended that "plans be prepared for the construction of Interstate Route 295." At the time, construction was planned to occur during the years 1960 to 1964 , to coincide with the completion of Interstate Route 95. (See Figure II ) Construction of the highway was called for to alleviate traffic congestion problems with through-traffic in Providence, and with travel between suburban areas. These problems, in conjunction with the absence of a welldeveloped mass transit system were viewed as the cause of fragmentation in the Rhode Island labor market and the reduction in the state's attractiveness to industry. ${ }^{2}$ The highway system in the state, especially in the Providence area, was extremely fragmented, and was seen as detrimental to the locale's development. At the time of highway planning, the city of Providence was losing population steadily. The eleven towns which I-295 was proposed to pass through or near were gaining actual population and in the 1950's accounted for nearly 70 percent of the state's population growth. (See Table XII for a list of the towns.) These trends have continued through 1960, 1970, and 1980. In 1980, the corridor towns held 37 percent of the total state population, while the population of Providence continued to decline.

The Basic Study Report prepared in 1962 for I-295 


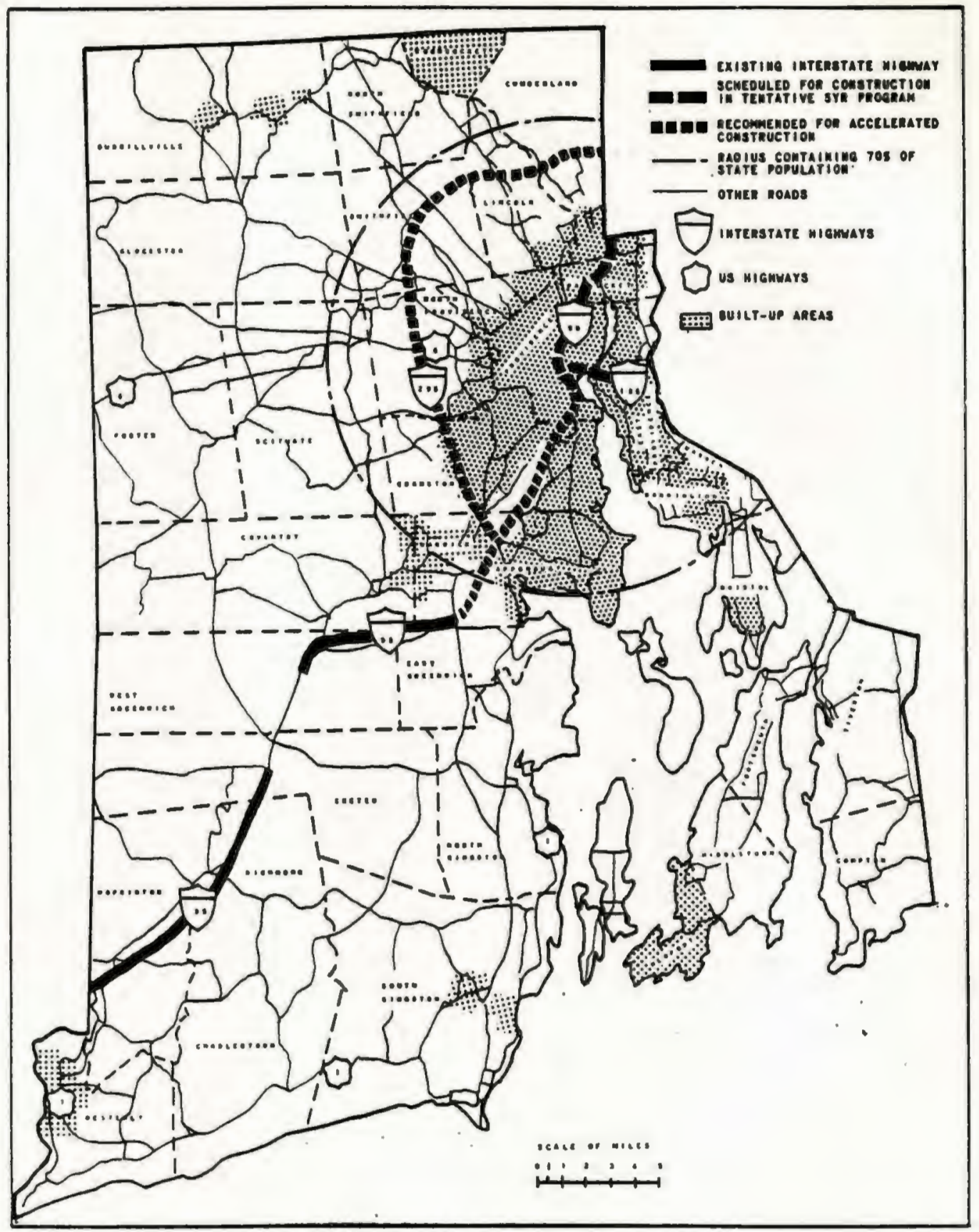

INTERSTATE HIGHWAYS RECOMMENDED FOR ACCELERATED CONSTRUCTION

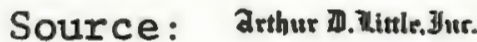




\section{TABLE XII}

A LIST OF THE RHODE ISLAND TOWNS

NEAREST TO ROUTE I-295

\begin{tabular}{|ll|}
\hline Coventry & Lincoln \\
Cranston & North Providence \\
Cumberland & North Smithfield \\
East Greenwich & Smithfield \\
Johnston & Warwick \\
& West Warwick \\
\hline
\end{tabular}

Source: Arthur D. Little, Inc., Industrial Development and Highway Planning in Rhode Island, (Cambridge, Massachusetts, 1959.) P.10. 
by Charles A. Maguire and Associates illustrated the belief that the highway held great development potential:

$$
\begin{aligned}
& \text { "Interstate Route } 295 \text { has the potential to } \\
& \text { attract commerce and industry to the Metro- } \\
& \text { politan Providence area in much the same } \\
& \text { manner as dramatically demonstrated by the } \\
& \text { extraordinary and prospering developments } \\
& \text { along Route } 128 \text { in Massashusetts." } 3
\end{aligned}
$$

The industry-attractive potential that the highway had was supported by employment figures and new plant construction in the 1950 's. Although the state's manufacturing employment was declining, the share of towns in the corridor increased. 4 In addition, the bulk of new plant construction was occurring in the suburbs, with nearly 60 percent taking place in the corridor towns in the 1950 's. ${ }^{5}$ (See Table XIII)

Although prosperous development scenarios were envisioned for Route 295 at its inception, the reality remains a question. A number of factors have been identified by local economic development officials. First, many feel that the state was errant in not providing a development plan for the highway corridor. With no specific development guidelines, the advantages of the corridor were lost. 6 Secondly, and equally important, is the lack of utiliites along much of the corridor. Water and sewage facilities have not been provided in many of the corridor communities, and according to one industrial develop- 


\section{TABLE XIII}

PLANT ADDITIONS, NEW BUILDINGS, AND

NEW PLANTS IN CORRIDOR TOWNS AND PROVIDENCE, $1955-1958^{1}$

\begin{tabular}{|lccccc|}
\hline Town & $\begin{array}{c}\text { Additions, New Buildings, } \\
\text { and New Plants } \\
\text { Square Footage }\end{array}$ & Number & \multicolumn{2}{c|}{ New Plants Only } \\
& 9000 & 1 & 9000 & 1 \\
\hline Coventry & 99750 & 34 & 38000 & 9 \\
Cranston & 1990 Footage & Number \\
Cumberland & 198500 & 4 & 120000 & 1 \\
East Greenwich & 475000 & 1 & 475000 & 1 \\
Lincoln & 19452 & 2 & 19452 & 2 \\
North Providence & 4500 & 1 & 4500 & 1 \\
North Smithfield & 89000 & 3 & 79000 & 2 \\
Warwick & 413300 & 18 & 51000 & 8 \\
\% of State Total & 58.7 & 41.3 & 87.6 & 69.5 \\
Providence & 455693 & 50 & 71607 & 4 \\
\% of State Total & 18.9 & 32.3 & 7.9 & 11.1 \\
\hline
\end{tabular}

1. Includes only eight of the eleven towns originally mentioned in the report.

Source: Arthur D. Little, Inc., Industrial Development and Highway Planning in Rhode Island, (Cambridge, Massachusetts, 1959) p. 16. 
ment commission member, "nothing has really developed because there are no sewers." 7 Other reasons for the relative lack of development success in many areas along the I-295 corridor are the many other available locations for industrial and commercial development in the state, along with its relatively slow economic growth. 8

\section{Key Elements in the City/Beltway Development Process}

Demographics

As stated in the previous section, Providence's population has been in decline since the 1940's. It decreased from a high in 1940 of 253,504 to the present level of 156,804 (1980), a decline of 38.1 percent. (See Table XIV ) The decline, although a continuing trend, is slowing somewhat.

The populations of each of the eight corridor towns have been steadily increasing since $1940 .{ }^{9}$ (See Table XV ) The largest increase in population has occurred in Smithfield, which had an increase of 266.2 percent from 1940 to 1980. Smithfield has continued to increase its population, with an addition of over 25 percent from 1970 to 1980. One town has decreased in population from 1970 to 1980 , by 3.1 percent. The towns currently (1980) hold a 62.2 percent share of the state's population growth, and 29.8 percent of its total population.

Both Providence and the eight towns are part of the Providence-Warwick-Pawtucket SMSA. Due to size of the SMSA, data was employed for the corridor towns only. 


\section{TABLE XIV}

\section{CHANGE IN PROVIDENCE POPULATION}

1940-1980

\begin{tabular}{|lcc|}
\hline Year & Population & Percent Change \\
\hline 1940 & 253,504 & - \\
1950 & 248,674 & -1.9 \\
1960 & 207,498 & -16.6 \\
1970 & 179,116 & -13.7 \\
1980 & 156,804 & -12.5 \\
$1940-80$ & - & -38.1 \\
\hline
\end{tabular}

Source: Rhode Island Department of Economic Development, Basic Economic Statistics 1982-83, R.I. Dept. of Economic Development, 1982 . 


\section{TABLE XY}

POPULATION TRENDS OF THE CORRIDOR TOWNS

\begin{tabular}{|lcccc|}
\hline Town & 1980 Pop. & $\begin{array}{c}\text { \% Change } \\
1940-80\end{array}$ & $\begin{array}{c}\text { \% Change } \\
1970-80\end{array}$ & $\begin{array}{c}\text { \% Nonwhite } \\
\text { Population, } 1980\end{array}$ \\
\hline Cumberland & 27,069 & 154.8 & 1.7 & 2.0 \\
Lincoln & 16,949 & 60.2 & 4.7 & 1.6 \\
Warwick & 87,123 & 203.0 & 4.1 & 1.7 \\
Smithfield & 16,886 & 266.2 & 25.4 & 1.1 \\
Johnston & 24,907 & 133.4 & 13.0 & 0.8 \\
Cranston & 71,992 & 52.9 & -3.1 & 2.4 \\
West & 27,026 & 48.6 & 11.1 & 2.4 \\
Warwick & & 137.7 & 6.7 & 1.0 \\
No. Smith- & 9,972 & & & \\
field & & & & \\
Total & 281,924 & & & \\
\hline
\end{tabular}

Source: Rhode Island Department of Economic Development, Basic Economic Statistics 1982-83, R.I Dept. of Economic Development. 


\section{Employment}

The largest sector of employment in the city of Providence historically has been manufacturing. (See Table XVI ) However, trends indicate movement away from that sector toward the services sector, which showed the greatest growth between 1960 and 1980, near1y 156 percent. It is one of the few sectors which has increased during the last twenty years. Manufacturing has also lost in its share of total employment, while the services sector increased from an 8.2 percent share in 1960 to a 32.8 percent share in 1980.

Total employment in the city has followed national trends, decreasing over 36 percent from 1960. In addition, the total number of establishments has decreased.

The Providence labor force has decreased over seven percent since 1970, while the unemployment rate has increased, following national trends.

The eight corridor towns are primarily oriented to manufacturing, the major industry sector for the past twenty years. (See Table XVII) There has been

a 63 percent increase $(1960-80)$ in the number of employees in the manufacturing sector within the corridor. This is due primarily to the increase in industrial parks in the area. There are presently eleven industrial parks located in the corridor. 
TABLE XVI

INDUSTRY OF EMPLOYED PERSONS

IN PROVIDENCE, 1960 - 1980

\begin{tabular}{|lcccc|}
\hline Sector & $\begin{array}{c}\text { Percent } \\
1960\end{array}$ & $\begin{array}{c}\text { Percent } \\
1970\end{array}$ & $\begin{array}{c}\text { Percent } \\
1980\end{array}$ & $\begin{array}{c}\text { Percent Change } \\
1960-1980\end{array}$ \\
\hline $\begin{array}{l}\text { Construction } \\
\text { \& Mining }\end{array}$ & 3.4 & 2.6 & NA & NA \\
$\begin{array}{l}\text { Manufacturing } \\
\text { Transportation } \\
\text { \& Communication }\end{array}$ & 46.0 & 42.9 & 31.7 & -56.0 \\
$\begin{array}{l}\text { Wholesale \& } \\
\text { Retail Trade }\end{array}$ & 23.8 & 21.9 & 16.4 & -68.8 \\
$\begin{array}{l}\text { Finance, In- } \\
\text { surance \& } \\
\text { Real Estate }\end{array}$ & 9.8 & 12.3 & NA & NA \\
$\begin{array}{l}\text { Services } \\
\begin{array}{l}\text { Public } \\
\text { Administration }\end{array}\end{array}$ & 8.2 & 11.3 & 32.8 & 155.8 \\
$\begin{array}{l}\text { Notal } \\
\text { Employment }\end{array}$ & 103,096 & 97,766 & 65,786 & NA \\
$\begin{array}{l}\text { Total Number } \\
\text { of Firms }\end{array}$ & 7,840 & 6,560 & NA & NA \\
\hline
\end{tabular}

Sources: U.S. Dept. of Commerce, 1980 County Business Patterns.

R.I. Dept. of Economic Development, Basic Economic Statistics 1982-83, (R.I. D.E.D., Providence, R.I., 1983). 
TABLE XVII

EMPLOYMENT TRENDS BY INDUSTRY

FOR THE I-295 CORRIDOR REGION, $1960-1980^{1}$

\begin{tabular}{|lrrrrrr|}
\hline Sector & 1960 & $\begin{array}{l}\% \text { of } \\
\text { Totàl }\end{array}$ & 1970 & $\begin{array}{l}\text { \% of } \\
\text { Total }\end{array}$ & 1980 & $\begin{array}{l}\% \text { of } \\
\text { Total }\end{array}$ \\
\hline $\begin{array}{l}\text { Agriculture, } \\
\text { Forestry \& }\end{array}$ & 178 & 0.6 & 199 & 0.4 & 354 & 0.4 \\
$\begin{array}{l}\text { Fishing } \\
\text { Mining }\end{array}$ & 67 & 0.2 & 84 & 0.2 & 72 & 0.1 \\
$\begin{array}{l}\text { Construction } \\
\text { Manufacturing }\end{array}$ & 1289 & 4.0 & 2663 & 5.3 & 2498 & 3.1 \\
$\begin{array}{l}\text { Transportation/ } \\
\text { Communications }\end{array}$ & 8786 & 64.6 & 26884 & 53.6 & 33726 & 41.8 \\
$\begin{array}{l}\text { Wholesale \& } \\
\text { Retail Trade }\end{array}$ & 5980 & 18.7 & 12740 & 25.5 & 22926 & 28.4 \\
$\begin{array}{l}\text { Finance, In- } \\
\text { surance, Real } \\
\text { Estate }\end{array}$ & 539 & 1.7 & 855 & 1.7 & 4362 & 5.4 \\
Services & 1856 & 5.8 & 4712 & 9.4 & 14581 & 18.1 \\
$\begin{array}{l}\text { Total } \\
\text { Employment }\end{array}$ & 31997 & & 50037 & & 80777 & \\
$\begin{array}{l}\text { Number of } \\
\text { Firms }\end{array}$ & 3586 & & 4529 & & 6315 & \\
\hline
\end{tabular}

1. All data was collected in the month of March in each respective year.

Source: R.I. Dept. of Employment Security, Employment Covered by R.I. Employment Security Act, 1960, 1970, 1980. 
The sector which show the greatest increases in employee numbers are services, finance, insurance and real estate, and wholesale and retail trade. This has been a result of the new office and retail construction occurring the southern part of the belt. ${ }^{10}$

Total employment in the towns increased over 150 percent between 1960 and 1980. (See Table XVII) The movement of population to the suburban areas, in addition to the shifting of manufacturers from city-based locations to outer regions have been the key factors in this increase.

Trends indicate a comparable rise in the total labor force residing in the corridor towns. (See Table XVIII) In 1980, the corridor region comprised nearly one-third of the state's total labor force, and 24 percent of its total employment.

\section{Income}

In all three census years examined, the median family income in the city of Providence is lower than that of the median income for the state. It has also increased at a slower rate than the Rhode Island median.

Median family income in the corridor region has increased at a somewhat faster rate than the state average, with the state figure on the low side of the corridor range. In all three years, the low end of the range has been higher than the median family income in Providence. (See Table XIX) 
TABLE XVIII

TRENDS IN THE LABOR FORCE OF THE CORRIDOR REGION, 1960 - 1980

\begin{tabular}{|lccc|}
\hline Year & $\begin{array}{l}\text { Number in } \\
\text { Labor Force }\end{array}$ & $\begin{array}{l}\text { Percent of } \\
\text { State Total }\end{array}$ & $\begin{array}{c}\text { Percent } \\
\text { Change }\end{array}$ \\
\hline 1960 & 89,579 & 24.9 & - \\
1970 & 117,215 & 28.0 & 30.9 \\
1980 & 142,297 & 30.6 & 21.4 \\
\hline
\end{tabular}

Source: Rhode Island Department of Economic Development, Basic Economic Statistics 1982-83, (R.I. D.E.D., Providence, Rhode Island, 1983) 


\section{TABLE XIX}

TREND IN THE RANGE OF MEDIAN FAMILY INCOME

IN THE CORRIDOR TOWNS, 1959, 1969, 1979

\begin{tabular}{|cccc|}
\hline Year & Corridor & Rhode Island & Providence \\
\hline 1959 & $\$ 5,549-6,390$ & $\$ 5589$ & $\$ 5,069$ \\
1969 & $\$ 9,485-11,311$ & $\$ 9,739$ & $\$ 8,430$ \\
1979 & $\$ 18,332-24,016$ & $\$ 19,448$ & $\$ 14,948$ \\
\hline
\end{tabular}

Source: R.I. Department of Economic Development, Basic Economic Statistics 1982-83, (R.I. D.E.D, Providence, R.I., 1983) 
Housing

The trends in numbers of building permits issued for residential units between 1965 and 1980 show that although fewer homes were built in Providence in 1980, the city's share of permits issued dropped by nearly fifty percent, and also lost in its share of the tota permits issued for Rhode Island. (See Table XX)

The number of single family homes in the city rose 68.7 percent between 1970 and 1980, while the total multifamily units dropped. In the corridor region, single family homes increased by over 28 percent from 1970 to 1980, and increased 12 percent in multifamily housing in the same period. (See Table XXI)

Economic - Retail/Commercial

The trend in retail sales for the city of Providence illustrates a loss of sales between 1970 and 1978 of 21 percent. During this time the corridor region gained in sales by 42 percent, supplementing a 136 percent gain in the 1962 to 1970 period.

Providence has higher per capita retail sales than the corridor region, although it decreased from 1970 to 1930. The corridor region increased over 150 percent between 1962 and 1978, while retail sales in the city increased only 38 percent during that time.

Four regional shopping centers have been constructed in the beltway corridor since 1965. (See Table XXII) Three of these centers, the Lincoln Mall, the Midland 
TABLE XX

TREND IN RESIDENTIAL BUILDING PERMITS

IN PROVIDENCE AND CORRIDOR REGION, 1965-1980

\begin{tabular}{|lrrrrrc|}
\hline Area & 1965 & $\begin{array}{c}\% \text { of } \\
\text { jtate }\end{array}$ & 1970 & $\begin{array}{c}\% \text { of } \\
\text { State }\end{array}$ & 1980 & $\begin{array}{c}\% \text { of } \\
\text { State }\end{array}$ \\
\hline Corridor & 1702 & 38.5 & 1579 & 33.0 & 865 & 29.6 \\
Providence & 164 & 3.7 & 235 & 4.9 & 193 & 6.6 \\
State & 4422 & - & 4790 & - & 2925 & - \\
\hline
\end{tabular}

Source: R.I. Department of Economic Development, Basic Economic Statistics, 1968, 1975, 1982-82.

\section{TABLE XXI}

NUMBER OF SINGLE AND MULTI-FAMILY HOMES

IN PROVIDENCE AND THE CORRIDOR REGION, 1970, 1980

\begin{tabular}{|lccccccc|}
\hline & \multicolumn{3}{c}{ Single family } & \multicolumn{4}{c}{ Multifamily } \\
Area & 1970 & 1980 & $\%$ & Change & 1970 & 1980 & $\%$ Change \\
\hline Corridor & 59,199 & 76,148 & 28.6 & 23,335 & 26,139 & 12.0 \\
Providence & 14,782 & 24,933 & 68.7 & 53,339 & 42,531 & -20.3 \\
\hline
\end{tabular}

Sources: U.S. Department of Commerce, U.S. Census of Housing, $1970,1980$. 


\section{TABLE XXII \\ REGIONAL SHOPPING CENTERS \\ BUILT AFTER 1965}

\begin{tabular}{|llcc|}
\hline Center & Location & Square Footage & Date Opened \\
\hline Apple Valley Mall & Smithfield & NA & 1966 \\
Lincoln Mall & Lincoln & 536,000 & NA \\
Midland Mall & Warwick & 483,248 & 1967 \\
Warwick Mall & Warwick & $1,009,196$ & 1970 \\
\hline
\end{tabular}

Source: The Providence Journal and Evening Bulletin, Shopping Centers in Rhode Island, 1982. 
Mall and the Warwick Mall are the three largest shopping centers in the state. The locations of the malls are illustrated in Figure III.

Construction of new commercial space, which includes office, hotel/motel, and banks, as well as retail, finds Providence in a declining trend. It has moved from a 30 percent share of the state's commercial construction to a six percent share between 1966 and 1980. (See Table XXIII)

The I-295 corridor has remained fairly consistent in its share of the state's new commercial construction, although the total amount built has been declining. In 1980, the corridor held a 36.7 percent share of the state total, while the city's share was 6.4 percent.

\section{Manufacturing}

In 1982 there were eleven industrial parks constructed adjacent to or within one mile of the Route I-295 beltway. (See Appendix II for a list of the parks.) There were over 830 total acres of industrial parks, of which 431 (52 percent) were occupied. The industrial areas occur primarily in the northern half of the belt, in the towns of Smithfield, Cumberland and Lincoln, where utilities and industrial zones are available. (See Figure IV)

Nearly 11,000 acres of land area in the corridor was zoned for industrial use in $1977 .^{11}$ Only 22 percent 


\section{FIGURE III}

LOCATIONS OF THE REGIONAL MALLS

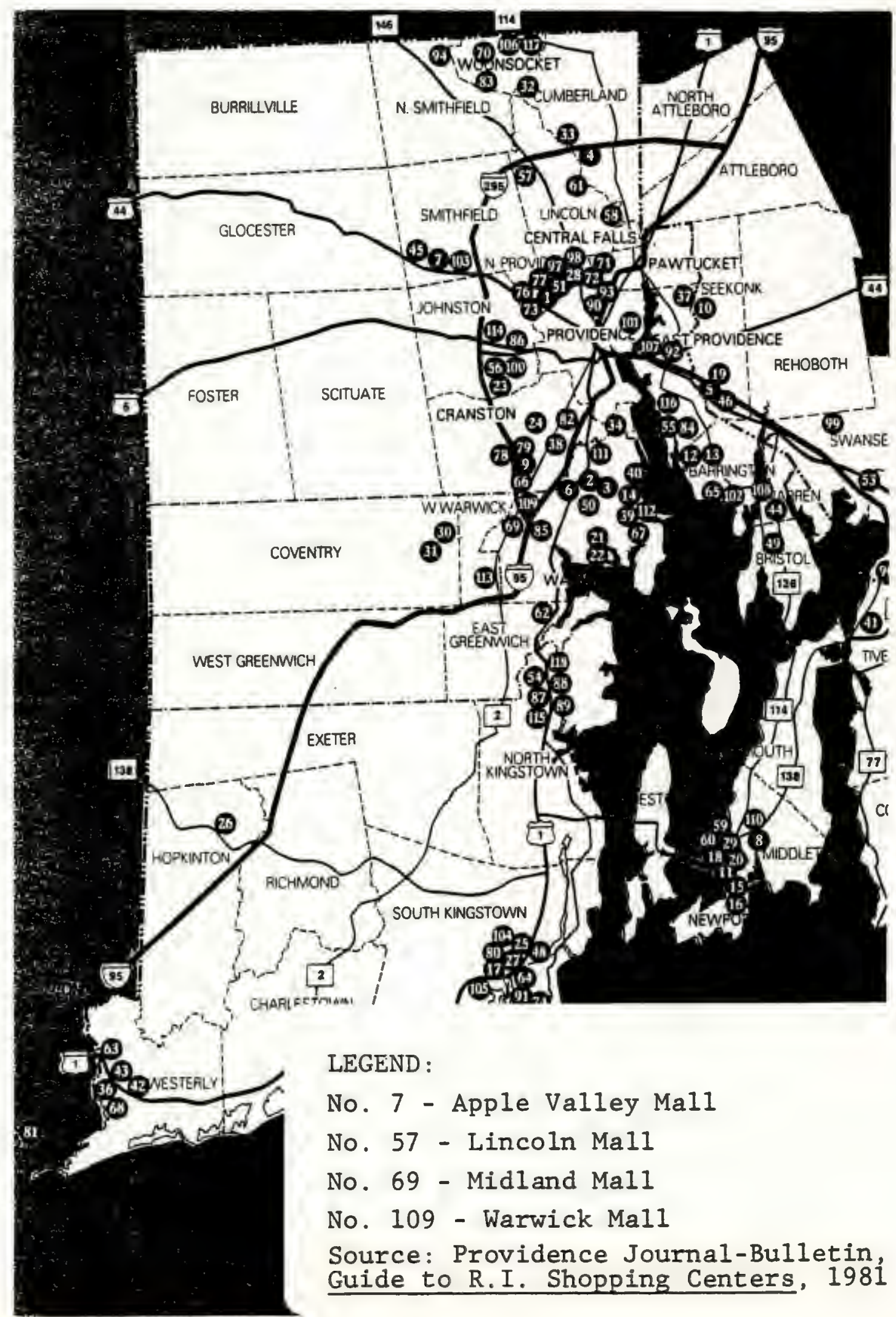




\section{TABLE XXIII}

NEW COMMERCIAL CONSTRUCTION

IN PROVIDENCE AND THE I-295 CORRIDOR, 1966-1980 1

(1,000's of Square Feet Floor Space)

\begin{tabular}{|c|c|c|c|c|c|c|}
\hline \multirow[b]{2}{*}{ Area } & \multicolumn{2}{|c|}{1960} & \multicolumn{2}{|c|}{1970} & \multicolumn{2}{|c|}{1930} \\
\hline & Total & $\begin{array}{l}\% \text { of } \\
\text { State }\end{array}$ & Total & $\begin{array}{l}\% \text { of } \\
\text { State }\end{array}$ & Total & $\begin{array}{l}\% \text { of } \\
\text { State }\end{array}$ \\
\hline Corridor & 891 & 38.8 & 548 & 28.1 & 338 & 36.7 \\
\hline Providence & 698 & 30.4 & $1022^{2}$ & 52.3 & 59 & 6.4 \\
\hline State & 2294 & - & 1953 & - & 921 & - \\
\hline
\end{tabular}

1. Projects of 50,000 square feet or greater. Incluaes office, retail, banks, and hotels.

2. Includes new Providence Civic Center. 


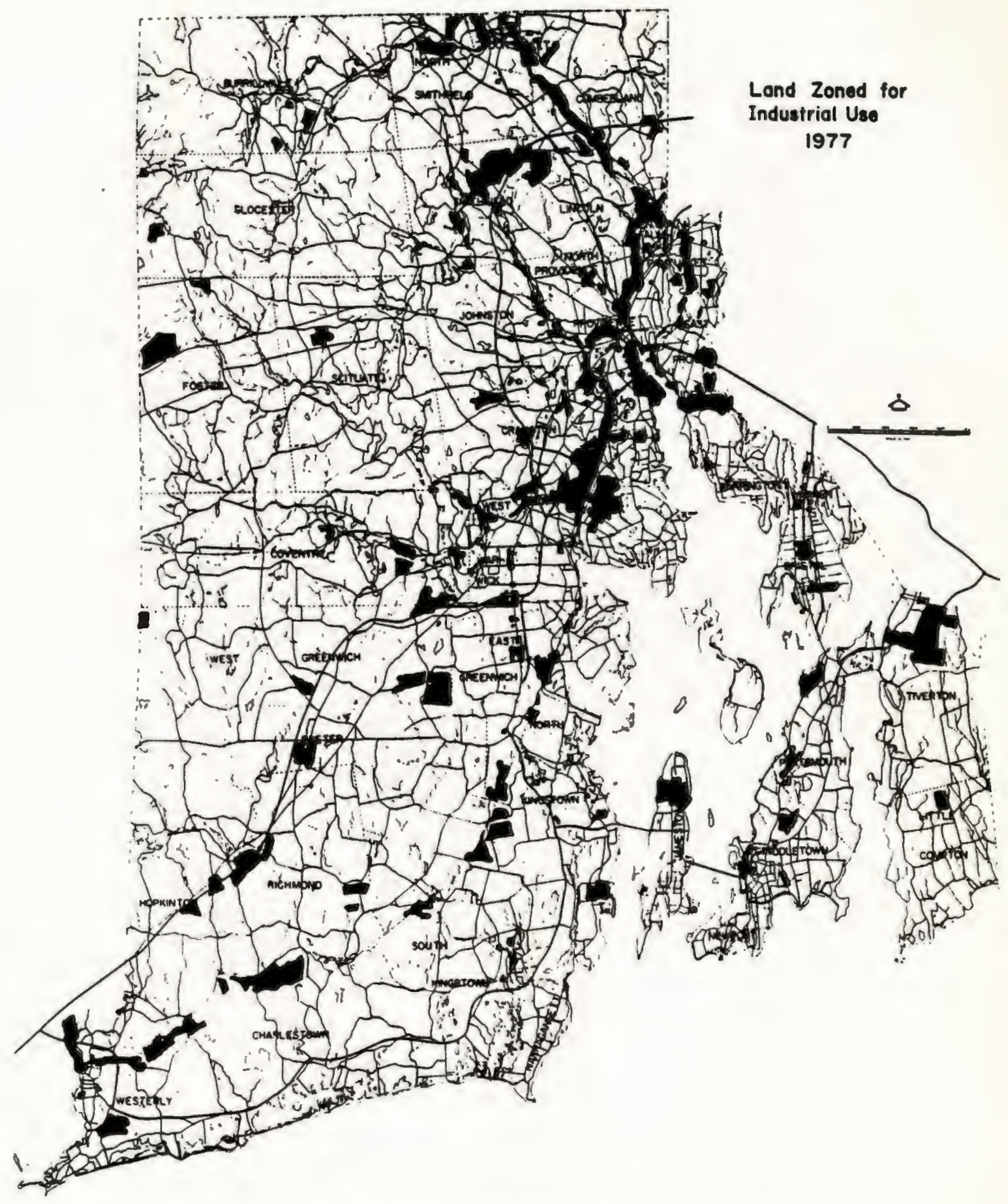

Source: R.I. Statewide Planning Program, Technical Report No. 76, 1978. 
of this, 2, 450 acres, was used for industry. Approximately half of the available zoned land was vacant in 1977. Lack of utilities appeared to be an important factor in this high vacancy figure, along with topographical and soil constraints. Over 19 percent of the sites lacked sewers, 5.7 percent lacked gas, and 3.3 percent did not have access to water. Approximately one-third of these zones contained some type of soil or topographical element which restricted development of the site. ${ }^{12}$

There are 46 sites zoned for industrial use within five miles of the I-295 beltway. 13 Eighty-five percent of these sites are partially or wholly occupied by some type of industry. This indicates a high percentage of vacant space in many of the industrial zones. In the city of Providence there were 2,312 acres of 1 and zoned for industrial use, of which over 50 percent were actually occupied by industry in 1977. Only 18 percent of the available sites were left vacant. All of the sites had utilities available, and most had good access to all major modes of transportation.

As stated in the employment section of this chapter, manufacturing is the largest employer in the corridor towns. In 1980 there were 919 manufacturing firms in the corridor, up from 627 in 1970, a 46.6 percent increase. The manufacturing sector was also the largest in Provi- 
TABLE XXIV

NEW CONSTRUCTION FOR MANUFACTURERS

IN PROVIDENCE AND THE CORRIDOR REGION

$$
1961-1981
$$

(1,000's of Square Feet of Floor Space)

\begin{tabular}{|lrrrrrrrrr|}
\hline & 1961 & 1962 & 1963 & 1964 & 1965 & 1966 & 1967 & 1968 & 1969 \\
\hline Providence & 496 & 83 & 142 & 123 & 231 & 198 & 294 & 246 & 121 \\
Corridor & 271 & 319 & 540 & 293 & 433 & 770 & 360 & 405 & 604 \\
& & & & & & & & & \\
\hline & 1970 & 1971 & 1972 & 1973 & 1974 & 1975 & 1976 & 1977 & 1978 \\
\hline Providence & 100 & 113 & 112 & 41 & 160 & 63 & 34 & 114 & 55 \\
Corridor & 548 & 571 & 1255 & 1083 & 439 & 150 & 766 & 677 & 365 \\
\hline & 1979 & 1980 & 1981 & & & & & & \\
\hline Providence & 79 & 21 & 46 & & & & & & \\
Corridor & 760 & 491 & 404 & & & & & & \\
\hline
\end{tabular}

Source: R.I. Department of Economic Development, Basic Economic Statistics, 1968, 1975, 1982-83. 
dence, but dropped 8.4 percent from 1970 to 1980.14 New construction of manufacturing firms in the corridor towns dropped from 548 in 1970 to 491 in 1980. This represented a -10.4 percent change. During the same time period, new manufacturing construction in Providence dropped 79 percent to the lowest number of starts in twenty years. ${ }^{15}$ (See Table XXIV)

\section{Land Use}

The 19.1 square miles which compose the city of Providence is comprised primarily of urban lands. 16 As in most cities, high density residential land makes up the majority of the space usage. Open and public lands follow, with a 12.0 percent share of the total. (See Table XXV)

Over seven percent of the city's land is in industrial use, of which 75 percent is heavy industry. Providence's transportation network also comprises a large percentage ( 9.5 percent) of its land area.

Forest 1and comprises nearly half ( 48 percent) of the total land area in the eight highway corridor towns. (See Table XXVI) It is followed by urban land (30 percent) and agricultural/open lands ( 13.3 percent). Development is inhibited in many corridor areas by topography and soil constraints, such as sharp slopes and rocky ledge. 
TABLE XXV

LAND USES IN THE CITY OF PROVIDENCE (1970)

\begin{tabular}{|lrc|}
\hline Land Type & Acreage & Percent of Total \\
\hline Urban Land & 10,107 & 82.7 \\
$\quad$ Industrial & 867 & 7.1 \\
Commercial & 1,353 & 11.1 \\
Residential & 5,254 & 42.9 \\
Transportation & 1,167 & 9.5 \\
Open and Public & 1,466 & 12.0 \\
Outdoor Recreation & 651 & 5.3 \\
Agriculture/Open & 123 & 1.0 \\
Forest Land & 526 & 4.3 \\
Wet Land & 795 & 6.5 \\
Mining, Waste & 22 & 0.2 \\
Total & 12,224 & 100.0 \\
\hline
\end{tabular}

Source: William P. MacConne11, Remote Sensing Land Use and Vegetative Cover in Rhode Island, Cooperative Extension Service, University of Rhode Island, 1974.

a) Due to the unavailability of current land use data by city and town, data presented is for the year 1970 unless otherwise stated. 


\section{TABLE XXVI}

\section{LAND USES IN THE I-295 CORRIDOR REGION}

\begin{tabular}{|lrr|}
\hline Land Type & Acreage & Percent of Total \\
\hline Urban Land & 37,475 & 29.9 \\
Industrial & 1,645 & 1.3 \\
Commercial & 2,357 & 1.8 \\
Residential & 25,623 & 20.4 \\
Transportation & 3,627 & 2.9 \\
Open/Recreation & 3,923 & 3.1 \\
Outdoor Recreation & 2,085 & 1.7 \\
Agriculture/Open & 16,633 & 13.3 \\
Forest Land & 60,157 & 48.0 \\
Wet Land & 7,850 & 6.3 \\
Mining/Waste & 1,523 & 1.2 \\
Total & 125,423 & 100.0 \\
\hline
\end{tabular}

Source: William P. MacConnell, Remote Sensing Land Use and Vegetative Cover in Rhode Island, Cooperative Extension Service, University of Rhode Island, 1974. 
Although open land predominates in the corridor, there has been increases in both commercial and industrial uses. This is especially true of the northern corridor towns, where utilities and zoning are wellsuited to industrial ust. ${ }^{17}$

Transportation - Highways

The regional transportation system of Providence and the surrounding towns centers around Interstate Route 95, which passes directly through the city. (See Figure. V ) The major radials connecting the city to I-295 and the outlying region are R.I. Route 146, U.S. Route 44, U.S. Route 6, R.I. Route 195, R.I. Route 14, R.I. Route 7, R.I. Route 122, and R.I. Route 114. Route I-95 south connects with I-295 at its southernmost point, in Warwick. The distance from any one point on Route I-295 to the center of Providence through this system of radials varies from 5 to 13 miles, with an estimated travel time of 10 to 20 minutes. 18

There are eleven interchanges along I 295 in Rhode Island, at the following locations:

1. R.I. Route 114 in Cumberland.

2. R.I. Route 122 in Cumberland.

3. R.I. Route 146 in Lincoln.

4. R.I. Route 7 in Smithfield.

5. U.S. Route 44 in Smithfield.

6. U.S. Route 6 in Johnston.

7. R.I. Route 195 in Johnston.

8. R.I. Route 14 at the Johnston/Cranston line. 
FIGURE

RHODE ISLAND HIGHWAY SYSTEM

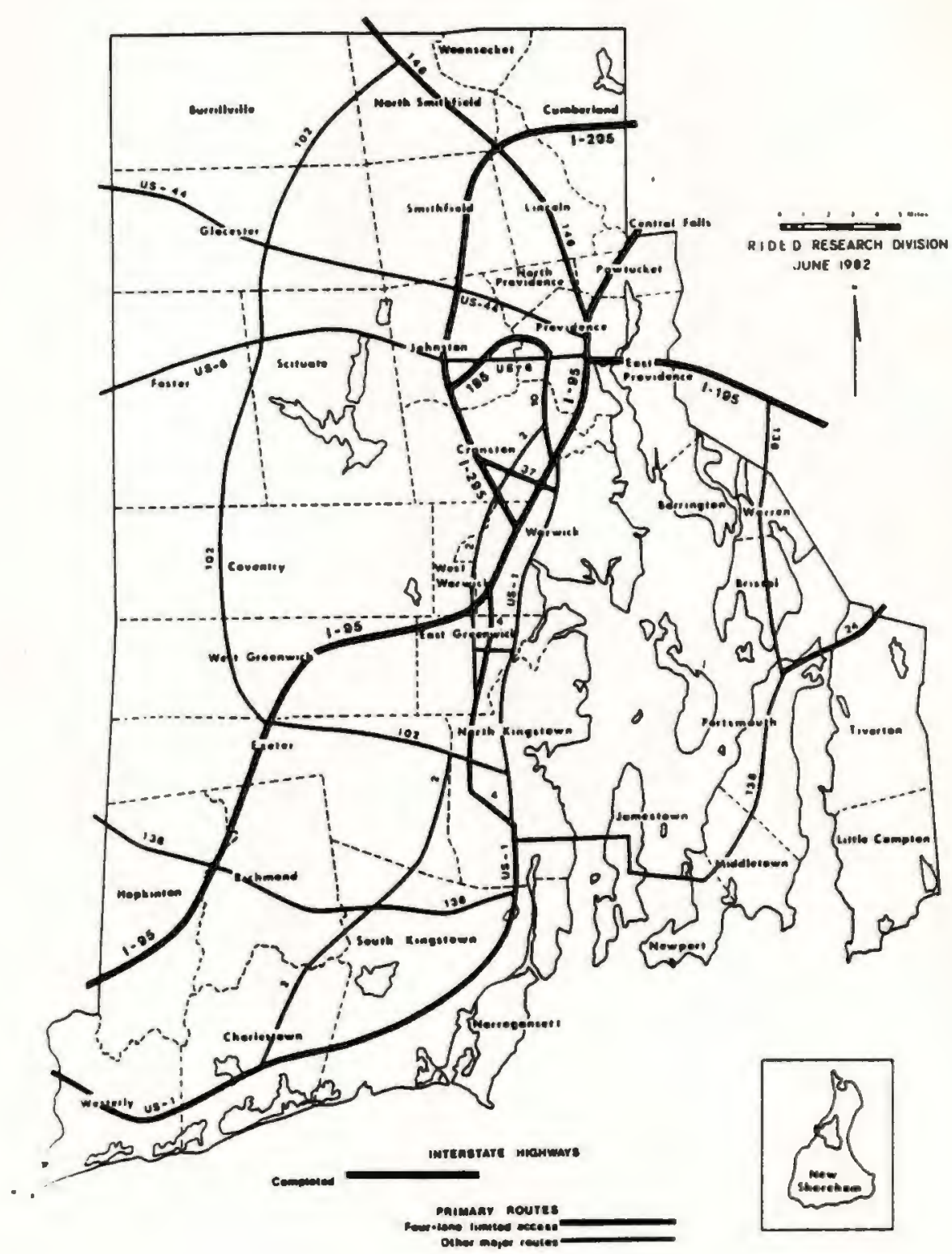


9. R.I. Route 37 in Cranston.

10. R.I. Routes 2 and 113 in Warwick.

11. Interstate Route 95 in Warwick.

The highway is approximately 23 miles in length, distributed as follows: Warwick, 1.5 miles; West Warwick, negligible mileage; Cranston, 4.3 miles; Johnston, 5.3 miles; Smithfield, 5.7 miles; Lincoln, 2.4 miles; Cumberland, 3.2 miles. The addition of Interstate Routes 95 and 295 has significantly reduced automobile travel times. Route 295 has played an important role in opening up the northwestern Rhode Island area to development. ${ }^{19}$ (See Figure VI)

Average daily traffic on the beltway has increased substantially since the completion of its last segments in 1975. (See Table XXVII) ${ }^{20}$ There has been a large increase at each of the counters located on I-295, with the exception of the Mendon Road to Diamond Hill Road segment, and the counter at the Massachusetts state line. Since the opening of the last segment of I-295, from Route 6 to Route 44, average daily traffic has increased by approximately 23,000 vehicles per day. In another substantial increase, traffic on the belt near the mall area increased by nearly 8,000 vehicles per day.

Transportation - Rail and Air

There are currently two freight lines which serve the corridor towns of Cranston, West Warwick, Lincoln 


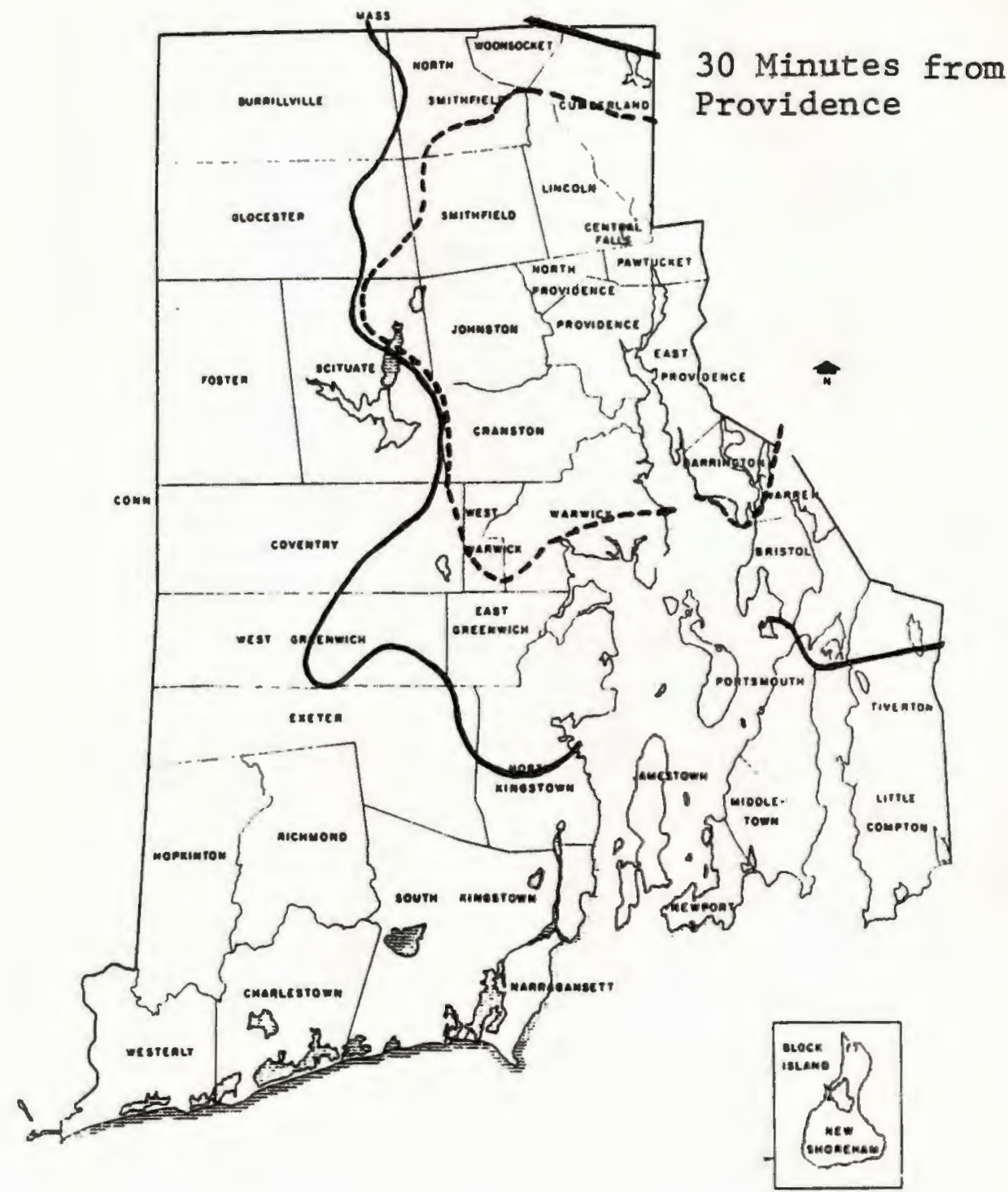

Source: R.I. Dept. of Economic Development, Basic Economic Statistics, 1982-83. (Providence, R.I., R.I. D.E.D., 1983.) 
TABLE XXVIII cont.

\begin{tabular}{|c|c|c|}
\hline $\begin{array}{l}\text { Area of } \\
\text { Concern }\end{array}$ & Indicator & $\begin{array}{l}\text { Availability } \\
\mathrm{X}=\text { Yes } \mathrm{N}=\mathrm{No}_{0}\end{array}$ \\
\hline \multirow[t]{7}{*}{ Land Use } & $\begin{array}{l}\text { Trend in City land uses } \\
\text { before and after belt } \\
\text { construction. }\end{array}$ & $\mathrm{N}$ \\
\hline & $\begin{array}{l}\text { Trend in belt region land } \\
\text { uses before and after belt } \\
\text { construction. }\end{array}$ & $\mathbf{N}$ \\
\hline & $\begin{array}{l}\text { Size of central city in } \\
\text { square miles. }\end{array}$ & $\mathrm{X}$ \\
\hline & $\begin{array}{l}\text { Average cost of land per } \\
\text { square foot in City. }\end{array}$ & $\mathrm{X}$ \\
\hline & $\begin{array}{l}\text { Average cost of land per } \\
\text { square foot in belt region. }\end{array}$ & $\mathrm{N}$ \\
\hline & $\begin{array}{l}\text { Location of development con- } \\
\text { straints in City. }\end{array}$ & $\mathrm{X}$ \\
\hline & $\begin{array}{l}\text { Location of development con- } \\
\text { straints in belt region. }\end{array}$ & $\mathrm{X}$ \\
\hline \multirow[t]{9}{*}{$\begin{array}{l}\text { Transporta- } \\
\text { tion }\end{array}$} & $\begin{array}{l}\text { Trend in average daily traf- } \\
\text { fic on beltway. }\end{array}$ & $\mathrm{X}$ \\
\hline & $\begin{array}{l}\text { Number of interchanges on } \\
\text { beltway. }\end{array}$ & $\mathrm{X}$ \\
\hline & $\begin{array}{l}\text { Spacing of interchanges on } \\
\text { beltway. }\end{array}$ & $\mathrm{x}$ \\
\hline & Length of beltway in miles. & $\mathrm{X}$ \\
\hline & Extensivenes of radial system. & $\mathrm{X}$ \\
\hline & $\begin{array}{l}\text { Evidence of pollution prob- } \\
\text { lems generated by belt. }\end{array}$ & $\mathrm{N}$ \\
\hline & $\begin{array}{l}\text { Usage of belt by public tran- } \\
\text { sit. }\end{array}$ & $\mathrm{N}$ \\
\hline & $\begin{array}{l}\text { Number of automobiles availa- } \\
\text { ble per family. }\end{array}$ & $\mathrm{X}$ \\
\hline & $\begin{array}{l}\text { Years of beltway construc- } \\
\text { tion. }\end{array}$ & $\mathrm{X}$ \\
\hline
\end{tabular}


TABLE XVIII cont.

\begin{tabular}{|c|c|c|}
\hline $\begin{array}{l}\text { Area of } \\
\text { Concern }\end{array}$ & Indicator & $\begin{array}{l}\text { Availability } \\
\mathrm{X}=\mathrm{Yes}^{-\mathrm{N}} \mathrm{N} \text { No }\end{array}$ \\
\hline \multirow[t]{4}{*}{$\begin{array}{l}\text { Economic: } \\
\text { Retail/ } \\
\text { Commercial }\end{array}$} & $\begin{array}{l}\text { Trend in location of re- } \\
\text { gional shopping centers } \\
\text { before and after beltway. }\end{array}$ & $\mathrm{X}$ \\
\hline & $\begin{array}{l}\text { New commercial construction } \\
\text { in beltway region. }\end{array}$ & $\mathrm{x}$ \\
\hline & Trend in City retail sales. & $\mathrm{X}$ \\
\hline & $\begin{array}{l}\text { Trend in beltway region re- } \\
\text { tail sales. }\end{array}$ & $\mathrm{X}$ \\
\hline \multirow[t]{3}{*}{ Office } & $\begin{array}{l}\text { Trend in location of new } \\
\text { office space in City after } \\
\text { beltway construction. }\end{array}$ & $\mathrm{N}$ \\
\hline & $\begin{array}{l}\text { Trend in location of new of- } \\
\text { fice space in beltway region } \\
\text { after construction. }\end{array}$ & $\mathrm{N}$ \\
\hline & $\begin{array}{l}\text { Proposed future construction } \\
\text { of office space in City. }\end{array}$ & $\mathrm{x}$ \\
\hline \multirow[t]{9}{*}{ Industry } & $\begin{array}{l}\text { Trend in location of indust- } \\
\text { rial parks after beltway con- } \\
\text { struction. }\end{array}$ & $\mathrm{x}$ \\
\hline & $\begin{array}{l}\text { New construction for manufac- } \\
\text { turers in City. }\end{array}$ & $\mathrm{x}$ \\
\hline & $\begin{array}{l}\text { New construction for manufac- } \\
\text { turers in beltway region. }\end{array}$ & $\mathrm{X}$ \\
\hline & Trend in industry mix in City. & $\mathrm{X}$ \\
\hline & $\begin{array}{l}\text { Available labor force in belt- } \\
\text { way region. }\end{array}$ & $\mathrm{x}$ \\
\hline & $\begin{array}{l}\text { Number and location of availa- } \\
\text { ble industrial zones in City. }\end{array}$ & $\mathrm{x}$ \\
\hline & $\begin{array}{l}\text { Number and location of availa- } \\
\text { ble industrial zones in belt- } \\
\text { way region. }\end{array}$ & $\mathrm{x}$ \\
\hline & $\begin{array}{l}\text { Number of industries relocated } \\
\text { to belt region from City. }\end{array}$ & $\mathbf{N}$ \\
\hline & $\begin{array}{l}\text { Trend in amount of available } \\
\text { space in City's industrial } \\
\text { parks. }\end{array}$ & $\mathrm{X}$ \\
\hline
\end{tabular}




\section{TABLE XXVIII}

THE AVAILABILITY OF INDICATORS FOR

USE IN THE I-295 CASE STUDY

\begin{tabular}{|c|c|c|}
\hline $\begin{array}{l}\text { Area of } \\
\text { Concern }\end{array}$ & Indicator & $\begin{array}{l}\text { Availability } \\
\mathrm{X}=\text { Yes } \mathrm{N}=\mathrm{No}\end{array}$ \\
\hline \multirow[t]{4}{*}{ Demographics } & Trend in City population. & $\mathrm{x}$ \\
\hline & $\begin{array}{l}\text { Trend in SMSA/County/Corri- } \\
\text { dor population. }\end{array}$ & $\mathrm{X}$ \\
\hline & $\begin{array}{l}\text { Trend in nonwhite City } \\
\text { population. }\end{array}$ & $\mathrm{X}$ \\
\hline & $\begin{array}{l}\text { Trend in SMSA/County/Corri- } \\
\text { dor population. }\end{array}$ & $\mathrm{X}$ \\
\hline \multirow[t]{6}{*}{ Employment } & $\begin{array}{l}\text { Trend in City employment by } \\
\text { industry class. }\end{array}$ & $\mathrm{X}$ \\
\hline & $\begin{array}{l}\text { Trend in SMSA/County/Corri- } \\
\text { dor employment by industry. }\end{array}$ & $\mathrm{x}$ \\
\hline & Unemployment rate in City. & $\mathbf{N}$ \\
\hline & $\begin{array}{l}\text { Unemployment rate in SMSA/ } \\
\text { County/Corridor. }\end{array}$ & $\mathrm{N}$ \\
\hline & Median family income of City. & $\mathrm{X}$ \\
\hline & $\begin{array}{l}\text { Median family income of SMSA/ } \\
\text { County/Corridor. }\end{array}$ & $\mathrm{X}$ \\
\hline \multirow[t]{6}{*}{ Housing } & $\begin{array}{l}\text { Total single/multifamily dwel- } \\
\text { ling units in City. }\end{array}$ & $\mathrm{X}$ \\
\hline & $\begin{array}{l}\text { Total single/multifamily dwel- } \\
\text { ling units in SMSA/County/ } \\
\text { Corridor. }\end{array}$ & $\mathrm{X}$ \\
\hline & $\begin{array}{l}\text { Trend in residential building } \\
\text { permits in City. }\end{array}$ & $\mathrm{x}$ \\
\hline & $\begin{array}{l}\text { Trend in residential building } \\
\text { permits in SMSA/County/Corri- } \\
\text { dor. }\end{array}$ & $\mathrm{x}$ \\
\hline & Year structure built in City. & $\mathbf{N}$ \\
\hline & $\begin{array}{l}\text { Year structure built in SMSA/ } \\
\text { County/Corridor. }\end{array}$ & $\mathrm{N}$ \\
\hline
\end{tabular}




\section{CHAPTER IV}

APPLICATION OF THE INDICATOR MODEL

TO THE INTERSTATE ROUTE 295 CASE

\section{Introduction}

The focus of this chapter is an application of the model (organizational framework) presented in Chapter III to the case study of Interstate Route 195, to determine impacts upon Providence, Rhode Island. It is organized into five areas of concern: demographics; employment; housing; economic, including retail/commercial, office, and manufacturing; 1 and use and transportation. Within these areas, the interrelationships between indicators are examined, and conclusions drawn as to whether the beltway has exerted a positive, neutral or negative influence upon the central city.

Although the majority of indicators selected for use within the model were available, some were not. A list of the indicators and their availability for use in this case study is presented in Table XXVIII.

\section{Analysis of Beltway Impacts by Area of Concern}

Demographics

The key indicator relationships within this section are those between the population of Providence and that of the corridor towns. The data show a steady decline in the city's aggregate population since 1940, while the corridor towns have all increased in population. This 
FOOTNOTES

1. Charles A. Maguire, Basic Study Report - Inter-

state Route 295: Warwick, West Warwick, Cranston,

Johnston and Smithfield (Boston, Mass : Charles A.

Maguire and Associates, Engineers, 1959.) p. 10.

2. Arthur D. Little, Inc., Industrial Development and Highway Planning in Rhode Island (Cambridge, Mass.: Arthur D. Little, Inc., 1959.)

3. Charles A. Maguire and Associates, P. 10.

4. Arthur D. Little, Inc., p. 14.

5. Ibid.

6. Gregg Krupa, title unknown, Providence JournalBulletin, November, 1, 1981, p. F-1.

7. Ibid.

8. Ibid.

9. The eight corridor towns examined in the remainder of the paper are those the beltway passes through, or nearly through: Cumberland, Smithfield, North Smithfield, Cranston, Johnston, Warwick, West Warwick, Lincoln.

10. Interview with Marcel Valois, Blackstone Valley Chamber of Commerce, Pawtucket, Rhode Island, April 11, 1983.

11. R.I. Statewide Planning Program, Land Zoned for Industrial Use - Technical Paper No. 76 (Providence, Rhode Island, R.I. Statewide Planning Program, November, 1978.) P.9.

12. Ibid., p. 12.

13. Ibid.

14. R.I. Department of Economic Development, Basic Economic Statistics - 1982-83 (Providence, Rhode Island, R.I. Dept. of Economic Development, 1983.) p. 94-95.

15. Ibid.

16. Urban lands are defined as residential, commercial, industrial and transportation larids. 
17. Dieter Hammerschlag, The Interstate Highway System and Urban Structure: A: Force for Change in Rhode Island (Providence, Rhode Island: R.I. Dept. of Transportation, 1976.) p. 33.

18. Rhode Island Dept. of Community Affairs, Major Industrial Sites on Interstate 295 in Rhode Island (Providence, Rhode Island: R.I. Development Council, 1970.) p. 2 .

19. Ibid., p. 295.

20. Interview with Marcel Valois.

21. R.I. Department of Economic Development, p. 110. 


\section{TABLE XXVII}

AVERAGE DAIIY TRAFFIC

ON ROUTE I-295

(1974, 1975, 1981)

\begin{tabular}{|lrrr|}
\hline Location & 197.4 & 1975 & 1981 \\
\hline $\begin{array}{l}\text { Near Warwick \& } \\
\text { Midland Malls } \\
\text { Plainfield Pike } \\
\text { to Rte. 195 }\end{array}$ & 10,400 & 13,800 & 21,700 \\
$\begin{array}{l}\text { Rte. 6 to } \\
\text { Rte. 44 }\end{array}$ & $\begin{array}{r}\text { Not } \\
\text { Open }\end{array}$ & 11,200 & 34,200 \\
$\begin{array}{l}\text { Louisquisset } \\
\text { Pike to Mendon } \\
\text { Road }\end{array}$ & 9,100 & 14,700 & 16,100 \\
$\begin{array}{l}\text { Mendon Road } \\
\text { to Diamond Hill } \\
\text { Road }\end{array}$ & 12,100 & 14,300 & 12,300 \\
$\begin{array}{l}\text { At the Massa- } \\
\text { chusetts line }\end{array}$ & 13,000 & 13,000 & 13,900 \\
\hline
\end{tabular}

Sources: R.I. Department of Transportation, Traffic Flow Map, 1981.

Providence Journal Bulletin, Paul A. Kelly, "Counts show traffic diminished at spots along Route 95," November 9, 1975. 
and Cumberland. Access to the main Conrail line is in downtown Providence. 21

The Theodore F. Green State Airport in Warwick, and the North Central State Airport on the Smithfield/ Iincoln town line provide the main air access to the Providence, I-295 area. The Theodore F. Green State Airport is the state's largest, and is located 12 minutes by vehicle from Providence. The North Central Airport serves primarily private air traffic.

Summary

This chapter has presented a compendium of data regarding Providence, Rhode Island and Interstate Route 295. The trends and changes are intended to show the impacts of the beltway upon Providence when set to the indicator model. In addition, the material represents an information system which can be employed in future studies of the highway and its impacts. 
illustrates a trend toward the suburbanization of the city. However, it is an outward movement which occurred before the initiation of beltway planning and construction. Therefore, the belt has probably had some affect on this trend, but is not solely responsible for the shift. This leads to a neutral ranking within the model structure.

The area in which the beltway did impact the suburbanization of population is in providing improved accessibility to towns which were previously lacking in such access. The state and town road system which served these towns previously, especially Cumberland, Smithfield and Johnston, did not provide for extensive accessibility. In this capacity, the beltway opened up more development opportunities in the outer region, while the city remained in its current mode. Since the beltway did not have a significant impact upon the city in this area, the neutral rating remains.

\section{Employment}

The indicator relationship which illustrates belt impact upon city employment is that between the employment by industry class, and the indicators of the retail/ commercial, office and manufacturing sections. The city of Providence has shown a shift in its employment mix from manufacturing to services in the past twenty years. Beltway construction has directly contributed to 
this shift. First, as the employment in the manufacturing sector in the city has dropped, manufacturing employment in the corridor towns has risen dramatically. Secondly, the amount of land available for the development of industrial sites in the corridor is much greater than in the city, due to the large differences in land area. This has lead to increased manufacturing construction in the corridor, weakening the amount of construction occurring in the city. This, in turn, leads to a loss in the city's share of manufacturing employment .

In addition, the corridor holds a much greater share of the new commercial construction that the city. This, coupled with the shifting population, removes much of the employment in the retail and wholesale trade sectors of the city. This is evident also by visual inspection of both areas. While the city has lost a number of its leading retail employers, the beltway corridor has gained four regional shopping centers and the employment generated by them. ${ }^{1}$

The employment sector of finance, insurance and real estate has remained fairly consistent in its share of Providence's total employment, while the same sector has increased over 700 percent in the corridor region. This is due primarily to the construction of a major 
insurance firm's headquarters in the city of Warwick in the early 1970's. While this appears to have had some impact on this sector in Providence, closer inspection finds that the belt had little impact in the relocation of this firm. The access provided by Route I-95 seems to have had more impact on its locational choice.

Thus the beltway has exerted primarily a negative impact upon the central city's employment sector. Again, it cannot be viewed as the sole cause of these alterations but as a major contributor. It appears that as the population moves outward, the businesses and employment opportunties follow.

\section{Housing}

The indicators employed to determine I-235's impact upon the housing conditions in Providence are the number of single and multi-family homes constructed, and the trends in residential building permits. The key concept in the examination of housing, as with population, is suburbanization.

The city of Providence has remained consistent in its total number of housing units, with the major share of that in multifamily housing. The corridor has gained nearly one quarter of its total number of units, and remains primarily single family oriented. It is not clear from these shifts whether I-295 has had a major impact upon the city. Rather it appears that it has 
exerted a positive impact in the corridor towns, and a neutral impact in the city.

While the total number of residential building permits has decreased for both the city and the corridor, the city has shown an increase in its share of the state's total housing units. At the same time. the corridor region has dropped in its share of the total units in Rhode Island. This information, coupled with the fact that the city has a higher number of multi-family units and the differences between median family income the city and the corridor, may indicate a trend toward movement back to the city by a certain segment of the population. This is viewed as a positive impact upon the city, and one in which Route I-295 is not playing an important role.

The overall impact of the beltway upon the city in the area of residential development and suburbanization is a neutral one. Other factors have had more of an affect upon the suburbanization of Providence than the construction of Route I-295, including the large network of radial highways along which the bulk of the new construction took place during the 1950's and 1960's.

\section{Economic - Retail/Commercial}

It is in this sector that the beltway has exerted definite impact upon Providence. Three main indicators 
have been selected to illustrate the shift in the city's retail sector. First, the trends in retail sales show a definite loss in the city's retail sales in the years before and after beltway construction. This loss has been a function of a complex set of factors, of which beltway construction is one. Since four regional shopping centers have been built in the corridor region since construction of the beltway began, retail dollars have risen sharply. At the same time, the city has lost its major anchor stores, and has taken a sharp drop in its share of Rhode Island's new commercial construction. The added accessibility, larger market area, and trend toward a private transportation oriented society have led to the negative impact of beltway construction upon the city's retail vitality.

Employment trends in the city also support this finding. There has been a substantial drop in employment in the retail and wholesale trade sector in Providence, and a corresponding leap in corridor employment in the sector.

Economic - Office

Data for the development of indicators in this category was unavailable. However, interviews with area planners and city officials provided some insight into the beltway impacts upon this category. ${ }^{2}$ The same commercial construction data employment in the retail/commercial category is applicable here since it includes 
office construction. This indicates the belt region holds a larger proportional share of new commercial construction in the state since beltway construction, including office space. The officials interviewed, however, felt that the highway had not had an extensive impact on the city's office sector. It was pointed out that employment in the service and finance sectors have grown since the initiation of belt construction, and that no large office projects have been undertaken in the beltway corridor, with the exception of the Metropolitan Life Insurance firm in Warwick, discussed in a previous section of this chapter.

In addition, the city is presently experiencing large gains in new office construction. Three major office centers have been completed, or are in the last stages of construction at the present time, and two additional office buildings are designated for completion in $1985 .^{3}$ The Capital Center Project, which is the largest single development project in Providence since the $1960^{\prime} \mathrm{s}$ is scheduled for completion in $1988 .{ }^{4}$ of the eleven designated parcels in the project, office space is the preferred use in nine. 5

Therefore, although quantifiable indicators are weak in this category, the neutral impact of the beltway on the city's office sector is visible. 


\section{Economic - Manufacturing}

There are a number of key indicator relationships which show the impact of I-295 upon Providence's manufacturing sector. First a comparison of the amount of developed industrial park area in the city and in the corridor towns is necessary. In Providence there are three industrial parks, comprising 330 acres. 6 Over 95 percent of these parks are actually developed. The acreage in industrial park use in the I-295 corridor was substantially larger (830+ acres) than in Providence, but only 50 percent of the parks were in a developed state in 1980. Occupancy of the industrial parks in the belt corridor has been slow, due to the unavailability of utilities in many areas adjacent to the beltway. ${ }^{7} \mathrm{Al}-$ though this indicator illustrates, in part, that industrial development was induced by the beltway, it does not show the impact of such development upon the city. Therefore, other indicator relationships are necessary.

The measure of new construction for manufacturers provides a more useful picture of the city and beltway trends. (See Chapter IV) In the early 1960's, when the initial beltway planning was underway, new manufacturing construction in Providence outdistanced that of the corridor towns. (See TableXIII) Soon after, however, new industry growth shifted to the outlying towns, and has been consistently higher in those towns since 
1962. In addition, while manufacturing employment in the city has decreased since beltway construction, it has increased in the corridor. This forms a key interrelationship which illustrates the attraction of manufacturing firms to the outlying corridor regions. ${ }^{8}$

There is also more potential for industrial growth in the corridor than in Providence. This is illustrated by the number and percentage of development of industrially zoned land. Over 50 percent of such land is developed in the city, while less that 25 percent of a substantially larger land area is developed in the corridor.

These indicator relationships, when viewed in the context of dynamic interaction, represent an overall negative impact of I-295 upon Providence's manufacturing sector. 


\section{Land Use}

The land use indicators employed in the model provide a profile of existing land uses within each geographic area. The main indicator relationships within this category show an assessment of the potential for growth in the city versus the beltway. Examination of the land uses in Providence shows a very low percentage of open space for development. The large number of forest and open acres in the corridor region shows a potential for substantial increased development. Therefore, it can be assumed that a larger proportion of future development will occur in the beltway region, rather than in the city. This assumption relies on a complex set of interrelated elements, including the provision of utilities in the beltway corridor, the attractive forces of the beltway versus those of other areas within the state, and the type of development that is predicted. For instance, trends show Providence is remaining the office center of the state, and there are no indications that the beltway towns will attract a substantial percentage of new office construction in the future. There are a number of factors underlying this trend. First, the belt area does not have any existing office centers, which would be an attraction to other office developers. Providence is the state center for office development, a trend which is projected to continue for the next ten years, at minimum. ${ }^{9}$ 
Second, the revitalization efforts of Providence businesspeople and municipal officials have been strong. A number of large development projects are underway, in addition to improved transportation facilities. 10 The city is being marketed, while the beltway corridor is not. This is playing, and will continue to play, an important tole in land use trends in both areas.

This example is not applicable to every functional area, for it is evident that areas such as manufacturing and retail trade will continue to thrive and grow in the beltway corridor. However, every revitalization or planning effort in the city will affect beltway development, and vice versa. Therefore, in considering the land use trends and future possibilities, planning should be a key focus.

In addition, to the growth potential in each area, development constraints must also be examined. Physical constraints, namely topography and slope, soils, wetlands, and extremely rocky areas, are development inhibitors, and direct where growth will occur. There are relatively few physcial constraints in the city, with its major inhibitor being the amount of existing development. In the beltway corridor, steep slopes, poor soils, rocky ledge and wetlands abound. ${ }^{11}$ Future development in this area will be directed by these constraints, and in turn, will affect the amount of development attracted to the belt corridor from the city. 
Transportation

There are four key points of analysis in this section. First, is the relationship between the beltway and the extensive radial system of highways connecting it to Providence. Second is the number of interchanges along the length of I-295, and the mileage within each corridor town. The third point is the trend in average daily traffic onthe beltway, and on the other major interstate serving Providence, Route I-95. Lastly, the other modes of transportation available and their proximity to both the beltway and city locations.

There are eight radial highways connecting the city of Providence with Route I-295, in addition to Route I-95. ${ }^{13}$ This highway system serves all of the corridor towns, and was in place for many years before I-295. Thus, it has been developed to a large extent, and has been a key factor in the suburbanization of Providence. The beltway has had little effect on the role this system plays in the city's transportation scheme. ${ }^{12}$ However, because the radials do intersect the beltway, forming prime locations for development, some impact must be assigned. To what extent such development has impacted the city is not determined.

The trends in average daily traffic on the belt have shown a marked increase since the completion of its final segments in 1975. Traffic figures for Route 
95 have also increased at most points. 14 This indicates that most in-state travelers have not begun to use I-295 as a connection to Providence and its surrounding suburbs. In addition, the average daily traffic figure for the Massachusetts state line, where I-295 crosses, has not shown a substantial increase. A stable figure here is an indication that through traffic has not been using I-295 as a bypass of Providence. These findings present an interesting pattern which seems to show little or no impact on traffic in the Providence area. The increases in average daily traffic on I-295 may be attributed to suburbanization factors, growth in development in the corridor towns, or a combination of the two.

The beltway's proximity to alternate modes of transportation is inconsequential to the city in this analysis. All other forms of transporation are closer to, or within the city limits. Thus, there does not appear to be any competitive advantage for the beltway in this area.

\section{Summary}

The analysis of interrelationships between selected indicators shows that I-295 has had somewhat of a neutral to negative impact upon certain functional area characteristics of the city of Providence. This conclusion results from the analysis of each area of concern, of which employment, retail/commercial, and manu- 
facturing were negatively impacted by the beltway, and all other categories having undergone little or no impact. While this finding does not comply fully with the case summary findings, it does follow the general trends. 


\section{FOOTNOTES}

1. The Outlet and Shepards Department stores have left the downtown in recent years.

2. Interviews with Susan Morrison, Rhode Island Office of Statewide Planning, Providence Rhode Island, April 12, 1983, and with Ted Green, Executive Director, Capital Center Commission, Providence, Rhode Island, April 18, 1983, and with Marcel Valois, Blackstone Valley Chamber of Commerce, Pawtucket, Rhode Island, April 11, 1983.

3. The General Services Administration building; One Empire Plaza; the J. Joseph Garrahy Judicial Complex.

4. The Old Stone Plaza and the Fleet/Gilbane Tower.

5. Skidmore, Owings and Merril1, Capital Center Design and Development Criteria, October, 1980.

6. Vincent Harrington, Industrial Parks in Rhode Island, (Rhode Island Department of Economic Development, Providence, Rhode Island, 1982)

7. Interview with Marcel Valois.

8. Interview with Marcel Valois.

9. Interview with Ken Orenstein, Director, Providence Foundation, Providence Rhode Island, April 15, 1983.

10. Interview with Ted Green.

11. U.S. Geological Survey, North Scituate Quadrangle, Georgiaville Quadrangle, Pawtucket Quadrangle, East Greenwich Quadrangle, Providence Quadrangle. (U.S. Department of the Interior, Washington, D.C., 1970, 1975.)

12. Interviews with Marcel Valois and Susan Morrison.

13. Rhode Island Department of Transportation, Traffic Flow Map, 1981. A radial highway is defined as one which radiates from the central city.

14. Rhode Island Department of Transportation, Traffic Flow Map, 1981. 
CHAPTER V

PROJECT CONCLUSIONS AND CRITIQUE

The focus of this research project was the development and testing of a particular methodology for use in the assessment of the social and economic impacts a beltway has upon the city it surrounds. The normative methodology of social and economic indicator analysis was chosen as the instrument through which this could be accomplished. In order to test the methodology, a case study was selected for an application of the model.

A number of conclusions as to the relative suitability of this type of methodology to assessment of beltway impacts have been made. First, indicator analysis proved to be a suitable mode through which to evaluate beltway impacts. Within the analysis, however, a variety of problems were encountered. The units of measure which were employed to assess the impacts of the beltway should be disaggregated to the highest extent possible. The aggregate units used, the city and the corridor towns, provided useful information, but at a gross level of aggregation. In addition, the analyst must employ comparable units of measure. A large variety of units will not allow an accurate picture of the beltway's impacts to be prepared. 
The second problem encountered within the model is the large number of variables (indicators) which are interrelated to form the composite beltway impact scenario. The number employed in this project proved to be manageable, but any increase in variables would require more sophisticated data synthesis processes. There is a danger of the model becoming oversimplified if the variable total is decreased, requiring the analyst to use caution when selecting the variables.

A third problem encountered in the development of this methodology was the extensive number of exogenous forces affecting a beltway's impacts upon a city. Without primary data, including surveys of residents, businesspeople, and govermment officials, many impacts cannot be wholly attributed to the beltway's existence. This is evident in attempting to assess suburbanization patterns, housing development patterns, and market changes. It is recommended that further social and economic indicator analyses of beltway impacts be designed to accomodate primary data in addition to secondary data.

The rating system developed to assess beltway impacts proved to be somewhat general in nature, not always allowing for an accurate sense of the direction an impact was moving. A more sensitive rating system should be developed for use in future indicator analyses of beltway impacts, one which is more closely related to the 
quantitative data.

The final problem encountered during the development and testing of this methodology was that of employing quantitative information to reach qualitative conclusions. It must be recognized that social and economic indicator analysis is a normative procedure, relying on direct, normative statistics which assess the relative direction in which a social process is moving. In order for this to occur, interplay between the quantitative and qualitative is required. However, as stated above, a more sensitive connection between the two should be developed.

In conclusion, this project determined that the methodology of social and economic indicator analysis was a suitable process for the assessment of beltway impacts upon selected functional areas within the city it surrounds. The methodology is not without its problems, however, and future applications of this type of analysis must address those problems. Social and economic indicator analysis is a methodology which, although fairly recently developed, is finding a place in many functional areas . 


\section{APPENDIX I \\ SUMMARIES OF BELTWAY IMPACT STUDIES}

\section{Introduction}

This appendix presents summaries of two case studies which were developed by the United State Department of Transportation. It is intended to illustrate the large number of measures which have been used in past studies of beltways and their impacts upon the cities they surround.

The two studies include the cities of Minneapolis and St. Paul, Minnesota, and Raleigh, North Carolina. The Department of Transportation chose to divide the case studies into four areas of concern: 1) demographics, 2) employment, 3) housing, 4) economic, including retail, office and manufacturing. In each case, the unit of measure selected was the Standard Metropolitan Statistical Area (SMSA), the county in which the city is located, and the city itself.

The Twin Cities of Minneapolis/St. Paul comprise a land area of roughly 107 square miles, and are surrounded by a beltway over 50 miles in length. In contrast, the city of Raleigh is 55 square miles in size, surrounded by a 14 mile beltway. Comparison of the population trends in the cities show Minneapolis/St. Paul decreasing in total numbers, while Raleigh has grown substantially from 1960 to 1980. In both cases the beltway was completed in 1970. 
Minneapolis/St. Paul - Interstate Routes 494 and 694

History

The Twin Cities are the larger of the two case studies presented in this appendix. Its beltway was constructed during the $1960^{\prime}$ s and runs entirely through suburban neighborhoods. The roadway follows the route of an older beltway, and is enclosed in the urban area of the two cities. ${ }^{1}$ (See Figure I )

An unusual feature of the beltway is the close spacing of interchanges (one mile or less). The Department of Transportation cites this, along with the vast system of radial highways serving the cities, as important features in analyzing the beltway's impact upon the cities. ${ }^{2}$

The strong revitalization program developed by a number of government agencies is the key to the Twin Cities' vitality, and has lessened the impacts the beltway would have had on the cities. ${ }^{3}$ Forces other than the beltway have been more consequential in the suburbanization of the two cities. The beltway, in fact, has had little affect on residential, retail, and industrial locations. ${ }^{4}$ The beltway had, however, provided a favorable location for new office construction in the 1970's

\section{Demographics}

The Twin Cities have shown a decrease in population from 1960 to 1980, with a decline of 19.3 percent. (See Table I ) They have also decreased in their share of 


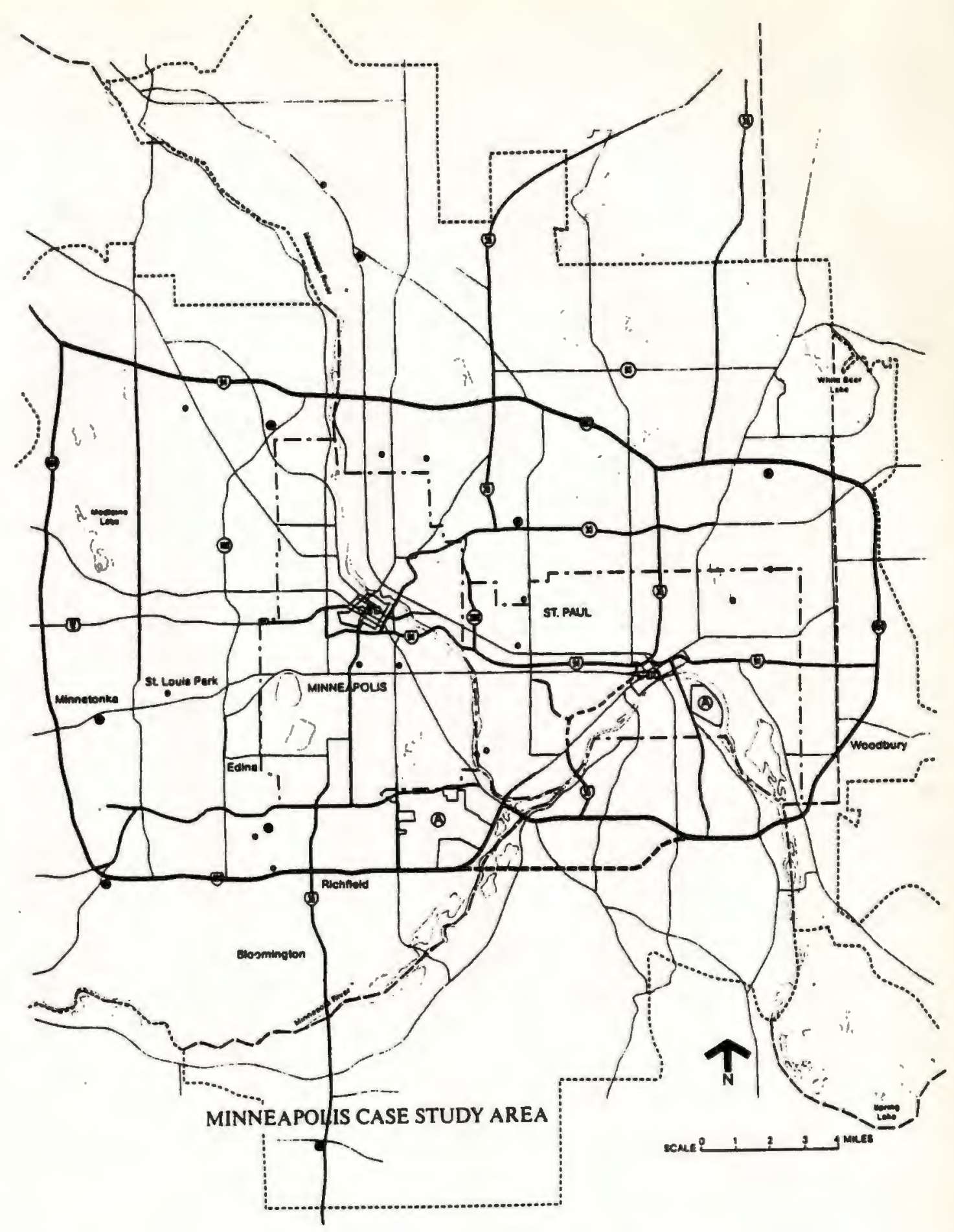

\section{FIGURE I.}

\section{LEGEND}

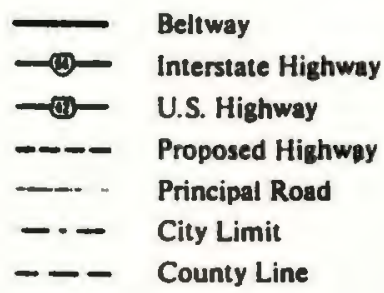

- Shopping Center $>400,000 \mathrm{Sq}$. Ft.

- Other Major Retail Center

- Industrial Part

cso Central Business District

(2) Airport 
SMSA population.

The metropolitan area has experienced a large increase in suburbanization during the past three decades, a factor which cannot be wholly attributed to the construction of the beltway. ${ }^{5}$ A number of other factors have contributed to this phenomenon, including increasing reliance on the automobile, a rising birth rate, federal income tax policies favoring the homeowner, and the increased availability of Federal Home Administration and Veteran's Administration home loans. 6

\section{Employment}

Manufacturing and the wholesale and retail sales sectors comprised the largest groups of employees in the Twin Cities in 1979. (See Table II ) However, the finance, insurance, real estate, service and government sectors have increased in employment during the last twenty-five years, indicating an increasing need for office space. 7

There has been some shifting of city residents from employment within the city to employment in outer suburbs within Hennepin and Ramsey Counties. This may be due to the trend of office space construction in these outer areas of the city. 8

Housing

Minneapolis/St. Paul has experienced a strong trend 


\section{TABLE I}

POPULATION IN MINNEAPOLIS/ST. PAUL, SURROUNDING

COUNTIES AND STANDARD METROPOLITAN AREA,

$\underline{1960-1980}$

\begin{tabular}{|lcllcl|}
\hline Year & $\begin{array}{l}\text { Minneapolis } \\
\text { and St. Paul }\end{array}$ & $\begin{array}{l}\text { Hennepin } \\
\text { and Ramsey } \\
\text { Counties }\end{array}$ & $\begin{array}{l}\text { Cities as a } \\
\text { Percent of } \\
\text { Counties }\end{array}$ & SMSA & $\begin{array}{l}\text { Cities as a } \\
\text { Percent of } \\
\text { SMSA }\end{array}$ \\
\hline 1960 & 795,000 & $1,434,000$ & 55 & $1,833,000$ & 43 \\
1970 & 744,000 & $1,436,000$ & 52 & $1,965,000$ & 38 \\
1980 & 641,180 & $1,401,195$ & 46 & $2,113,533$ & 30 \\
\hline
\end{tabular}

Source: U. S. Department of Transportation, The Land Use and Urban Development Impacts of Beltways, $1980, \mathrm{p} . \mathrm{M}-3$. 


\section{TABLE II}

DISTRIBUTION OF NON-AGRICULTURAL EMPLOYMENT

IN MINNEAPOLIS/ST. PAUL SMSA BY SECTOR - 1979

\begin{tabular}{|lc|}
\hline Sector & Percent of Total \\
\hline Construction, Mining & 5.4 \\
Manufacturing & 23.0 \\
Transportation, Public Utilities & 6.2 \\
and Communications & 24.6 \\
Wholesale and Retail Trade & 6.5 \\
Finance, Insurance and & 20.9 \\
Real Estate & 13.4 \\
\hline Services & \\
\hline
\end{tabular}

Source: U.S. Department of Transportation, The Land Use and Urban Development Impacts of Beltways - Case Studies, 1980 , p. M-5. 
toward suburbanziation, beginning in the 1950's. As suggested previously, many factors have influenced this residential development pattern. ${ }^{9}$ However, since the beltway was not constructed until the 1960's it did not have an appreciable affect on suburbanization. Although many residences have located on the radial highways in the area between the city and the beltway, less housing development has occurred along the beltway itself. This can be seen in Figure II, which illustrates residential development patterns in the Twin Cities metropolitan area.

Economic - Retail/Commercial

The Twin Cities Beltway has had some effect on the location of retail and commercial establishments in the area. Three of the region's eight major retail centers are located on the belt, and with the exception of one, all were built more recently than the five non-beltway centers. ${ }^{10}$ (See Figure III)

Retail sales trends indicate a greater rise in Standard Metropolitan Statistical Area sales than in central cities sales. One Central Business District, St. Paul, actually deceased in retail sales from 1958 to 1977. As a percentage of the Standard Metropolitan Statistical Area, the central cities again declined in retail sales. ${ }^{11}$ (See Table III) 


\section{FIGURE II}

\section{RESIDENTIAL DEVELOPMENT PATTERNS}

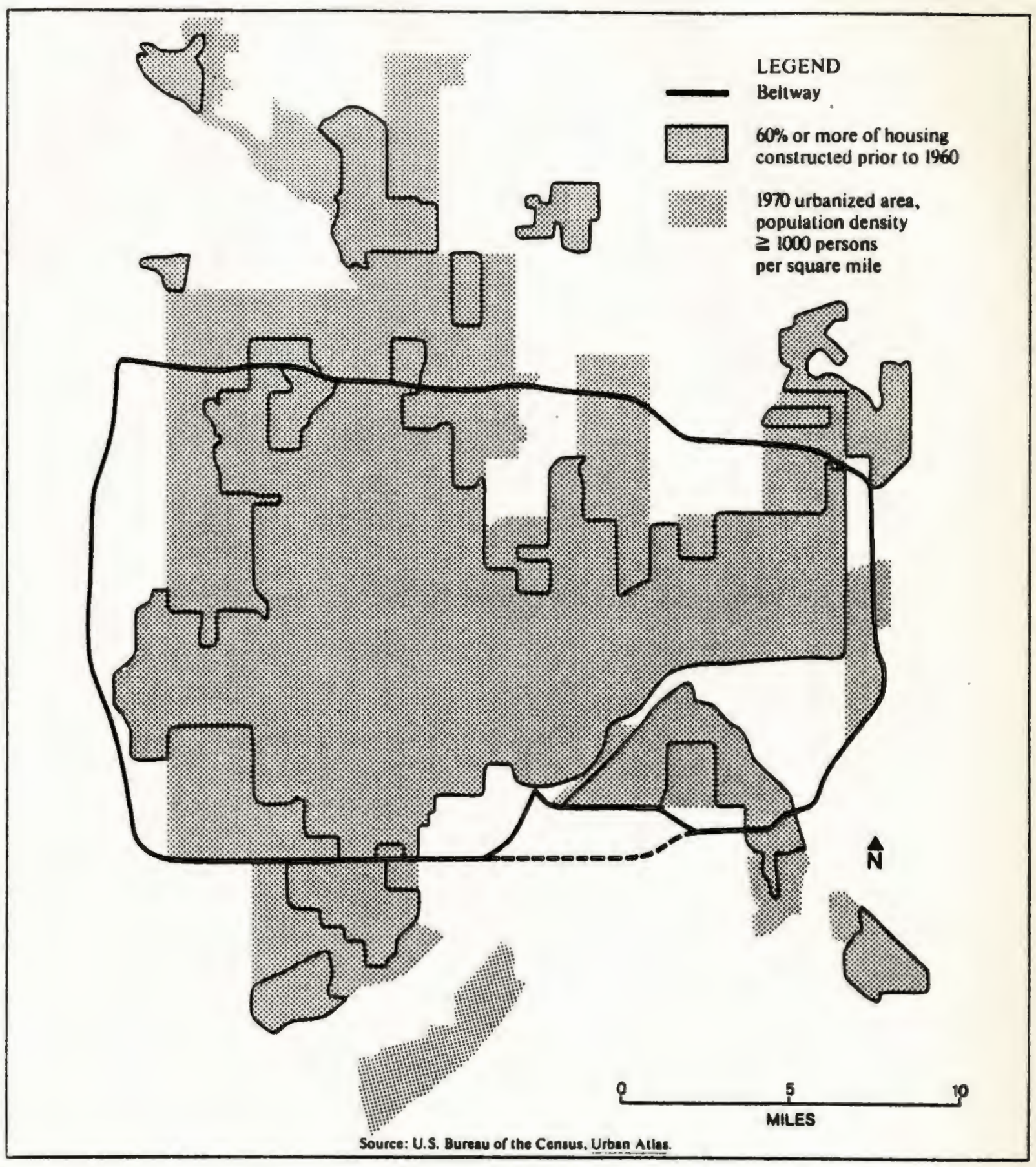

Source: U.S. Dept. of Transportation, The Land Use and Urban Development Impacts of Beltways-Case Studies, 1980 . 


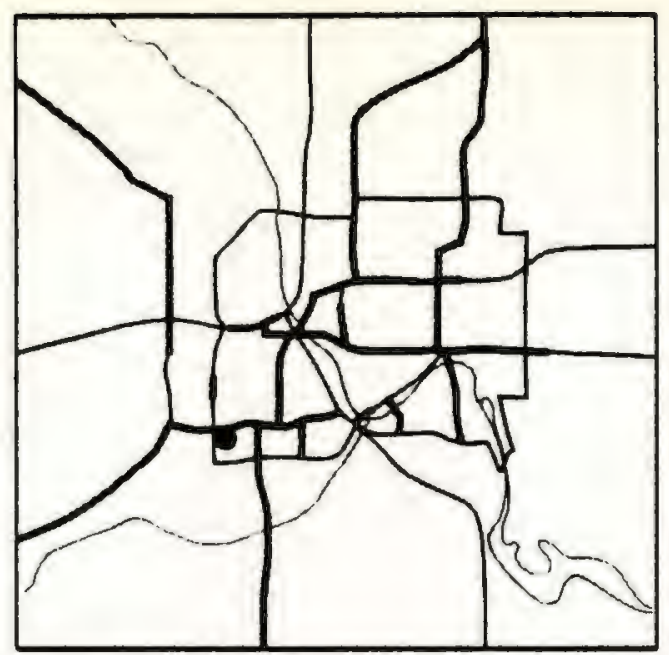

Pre 1957

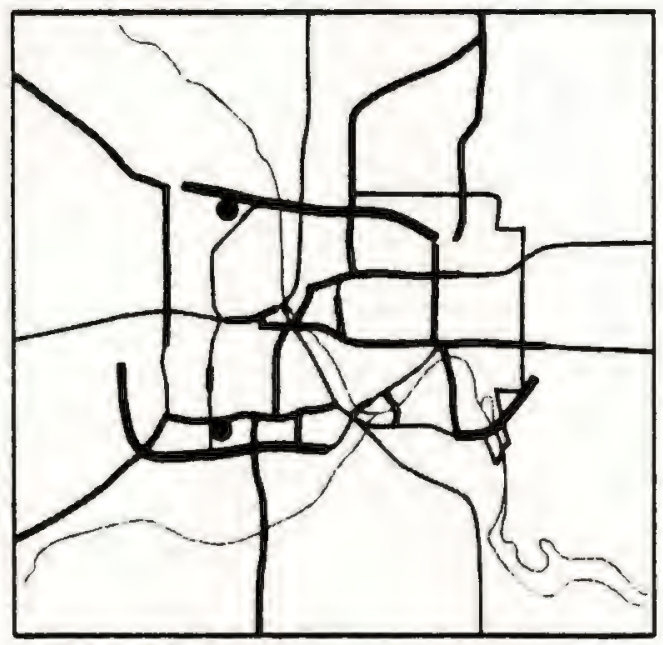

1961-1965

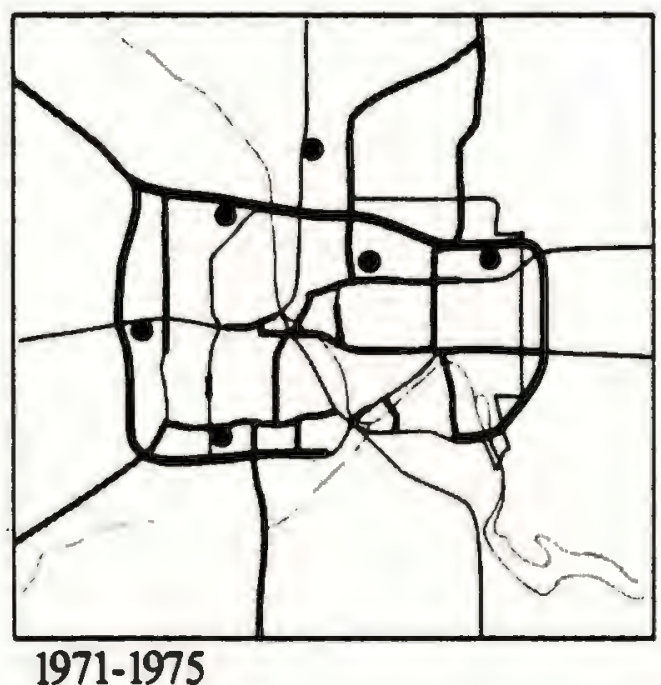

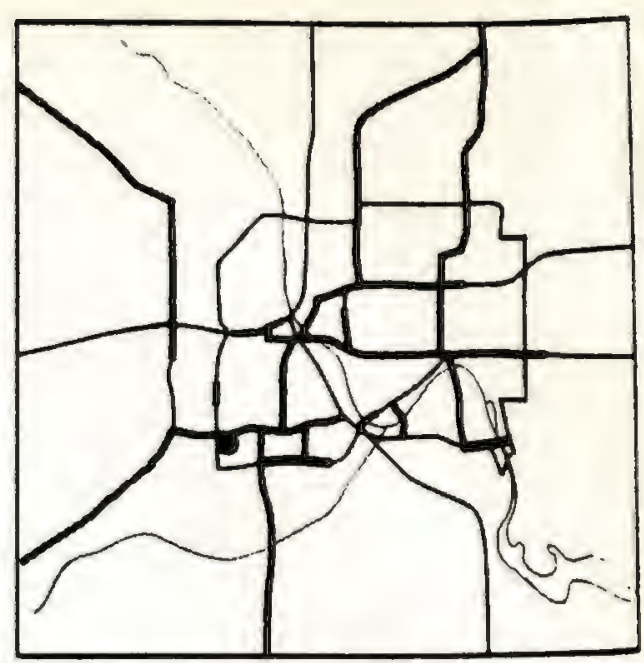

$1957-1960$

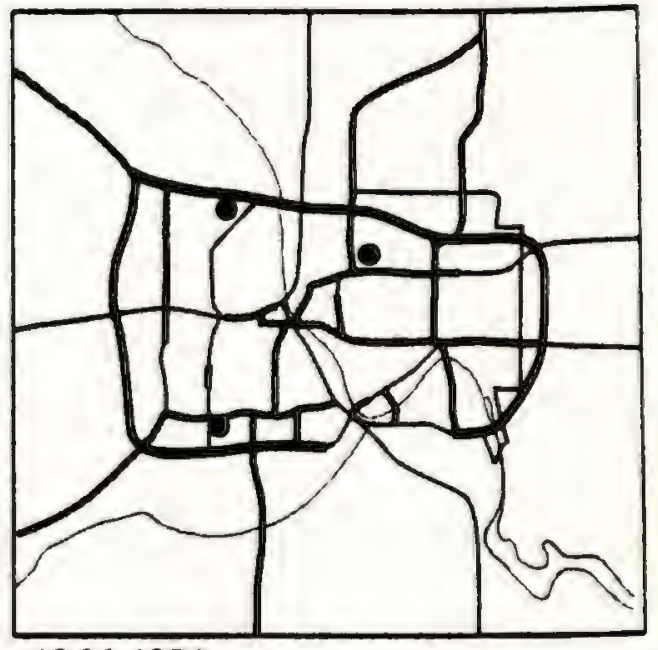

$1966-1970$

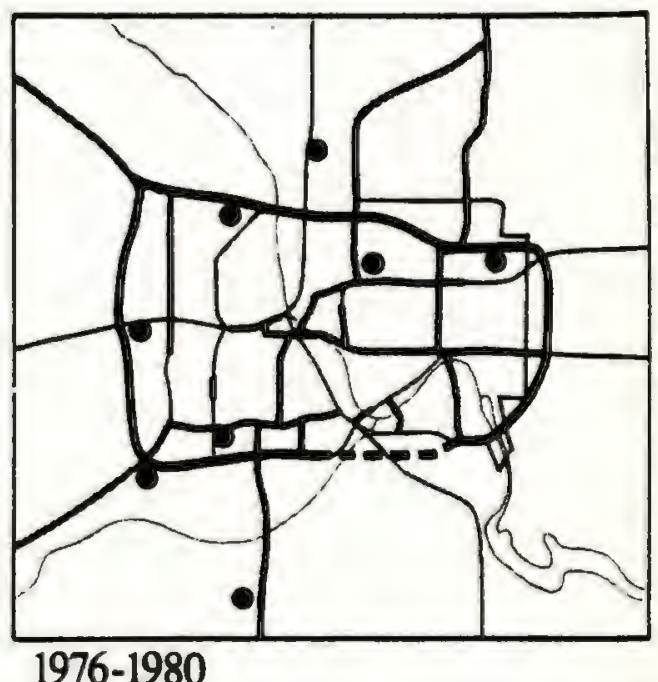

EVOLUTION OF THE MINNEAPOLIS BELTWAY 


\section{TABLE III}

RETAIL SALES TRENDS:

MINNEAPOLIS/ST. PAUL $1958-1977^{1}$

\begin{tabular}{|rrrrrrc|}
\hline Area & 1958 & 1963 & 1967 & 1972 & 1977 & $\begin{array}{c}\text { Average } \\
\text { Annual } \\
1958-1977\end{array}$ \\
\hline $\begin{array}{l}\text { SMSA } \\
\begin{array}{l}\text { Central } \\
\text { Cities }\end{array}\end{array}$ & 1729 & 3084 & 2836 & 4488 & 7281 & 7.9 \\
$\begin{array}{l}\text { Minneapolis } \\
\text { CBD }\end{array}$ & NA & 256 & 281 & 285 & 325 & 1.7 \\
$\begin{array}{l}\text { St. Paul } \\
\text { CBD }\end{array}$ & NA & 1258 & 1483 & 1673 & 2171 & 3.0 \\
$\begin{array}{l}\text { Both CBDs } \\
\text { CBD as a }\end{array}$ & 401 & 360 & 398 & 390 & 416 & 0.2 \\
$\%$ of SMSA & 23 & 17 & 14 & 9 & 6 & - \\
\hline
\end{tabular}

1. In millions of dollars.

Sources: U.S. Department of Transportation, The Land Use and Urban Development Impacts of Beltways - Case Studies, 1980 , p. M-19.

U.S. Bureau of the Census, Census of Retail Trade 
In 1977, retail centers located within one mile of the beltway had $\$ 316$ million in sales, or 76 percent of the total sales in the two Central Business Districts.

\section{Office}

The late 1970's found the majority of private office space in the Twin Cities located in the two central business districts. Suburbs inside and outside the beltway, and the beltway corridor itself captured nearly 34 percent of the office space. New office construction on and around the highway showed its greatest increase in the early to mid-1970's 12 (See Table IV )

\section{Industry}

The Minneapolis/St. Paul area has experienced a shift in industrial locations from the central cities to the suburbs surrounding the beltway. Studies undertaken in 1979 indicated that firms which were moving held good transportation and sewer service to be among the most important determinants in relocation. ${ }^{13}$ (See Figure IV ) The beltway was an important factor in the relocation of these industries, along with the massive urban renewal taking place in the central cities, and the excellent radial system of highways. 14 
TABLE IV

CHANGE IN LOCATION OF

PRIVATE OFFICE SPACE 1970 - 1976

\begin{tabular}{|c|c|c|c|}
\hline Area & $\begin{array}{l}\text { Pre - } 1970 \\
\text { Percent } \\
\text { Distribution }\end{array}$ & $\begin{array}{l}\text { New Construction } \\
\text { Percent } \\
\text { Distribution } \\
\end{array}$ & $\begin{array}{l}\text { Office Space } \\
\text { Percent } \\
\text { Distribution }\end{array}$ \\
\hline $\begin{array}{l}\text { Minneapolis } \\
\text { CBD }\end{array}$ & 36.4 & 21.8 & 32.0 \\
\hline $\begin{array}{l}\text { St. Paul } \\
\text { CBD }\end{array}$ & 29.0 & 14.5 & 24.6 \\
\hline $\begin{array}{l}\text { Remainder } \\
\text { Central } \\
\text { Cities }\end{array}$ & 13.1 & 1.4 & 9.6 \\
\hline $\begin{array}{l}\text { Suburbs } \\
\text { Inside } \\
\text { Beltway }\end{array}$ & 11.3 & 21.1 & 14.3 \\
\hline Beltway & 7.3 & 32.5 & 14.9 \\
\hline $\begin{array}{l}\text { Suburbs } \\
\text { Outside } \\
\text { Beltway }\end{array}$ & 2.9 & 8.6 & 4.6 \\
\hline Total & 100.0 & 100.0 & 100.0 \\
\hline
\end{tabular}

Source: U.S. Department of Transportation, The Land Use and Urban Development Impacts of Beltways - Case Studies, 1980 , p. M-21. 


\section{FIGURE IV}

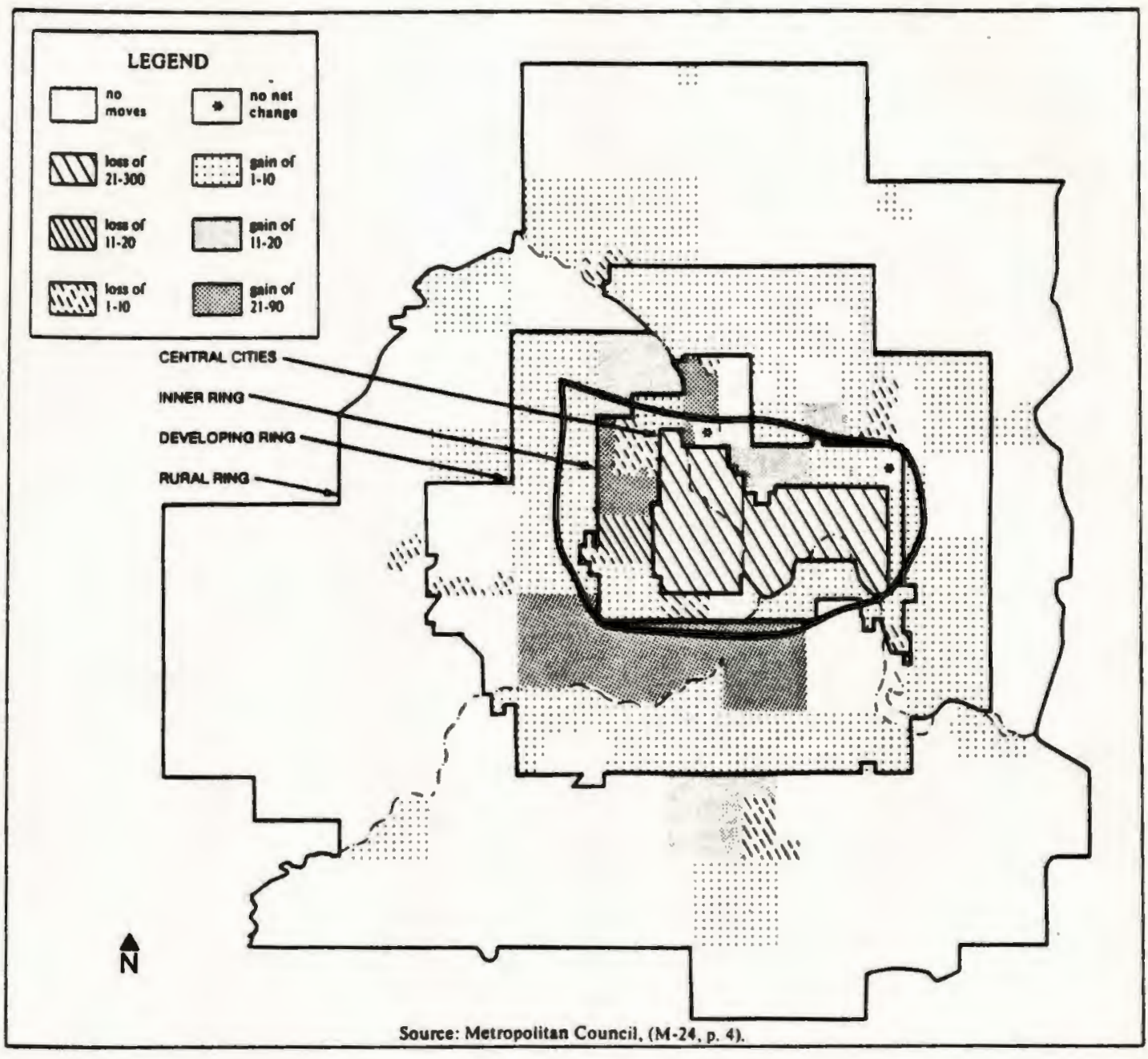

\section{MOVEMENT OF INDUSTRIAL FIRMS BETWEEN JURISDICTIONS, 1960-1977}

Source: U.S. Department of Transportation, The Land Use and Urban Development Impacts of Beltways (U.S. Government Printing Office, Washington, D.C., I980) 


\section{Summary}

The beltway which surrounds the cities of Minneapolis and St. Paul was built as an upgraded connector for the vast system of radial highways in the area. According to the U.S. Department of Transportation, it met this criteria with success. In addition, the beltway has provided a number of unintended impacts to the cities it surrounds.

Suburbanization patterns, which are the focus of the trends in demographics and housing, show a shift of population from the cities to the outlying regions. Housing starts have also followed this trend. ${ }^{15}$ The impact that the beltway has had upon these shifts has been minimal, due to the large and complex set of factors which were involved in suburbanization, and because beltway construction began well after the initial trend toward suburbanization. 16

Employment has also shown shifts in geographic location, primarily in the office sectors. 17 When viewed in conjunction with the increased number of offices constructed in the beltway corridor versus the Central Business District, a negative impact upon city employment is evident.

The roadway had an extensive impact upon the retail, office and industry sectors of the cities. In all sectors, trends showed movement of employment, infrastructure, and sales dollars to the beltway region. 


\section{FOOTNOTES}

1. U.S. Department of Transportation, The Land Use and

Urban Development Impacts of Beltways - Case Studies,

(U.S. Government Printing Office, Washington, D.C.,

1980). P. M-12.

2. Ibid., p. M-2.

3. Ibid., p. M-3.

4. Ibid., p. M-2.

5. Ibid., p. M-3.

6. Ibid.

7. Ibid.

8. Ibid., p. M-14.

9. Ibid., P. M-16.

10. Ibid., P. M-20.

11. Ibid., p. M-21.

12. Ibid., p. M-22.

13. Ibid., p. M-24.

14. Ibid.

15. Ivid., p. M-25.

16. Howard P. Chudacoff, The Evolution of American Urban Society, (Prentice-Hall, Englewood Cliffs, N.J. 1981), pp. $75-76$.

17. U.S. Dept. of Transportation, p. M-22. 
Raleigh, North Carolina - U. S. Routes 1 and 64

History/Setting

The "Beltline" surrounding the city of Raleigh, North Carolina is comprised of U.S. Routes 1 and 64. It was built as a solution to downtown congestion problems resulting from six state and federal highways which converged upon the city. As of 1980 , the southern part of the beltway was still under construction. (See Figures $V$ and VI)

Since the first parts of the belt were completed between 1960 and 1964 traffic has greatly increased. This is partly due to the large increases in population the city has experienced between 1960 and 1980, a 60 percent increase.

Raleigh itself is substantially different from the other case study cities examined in this report. Its primary employment areas are in government, services and trade, and it is not surrounded by suburban communities. In addition, it appears that the beltway has exerted various pressures on the city in the areas of housing, offices, and retail development. The city has lost much of its retail activity to centers along the beltway, where customers have excellent access to shopping and free parking. The city is also concerned with the loss of office space to the Beltline. Over 50 percent of new office space was constructed on the belt during the years of major construction. 


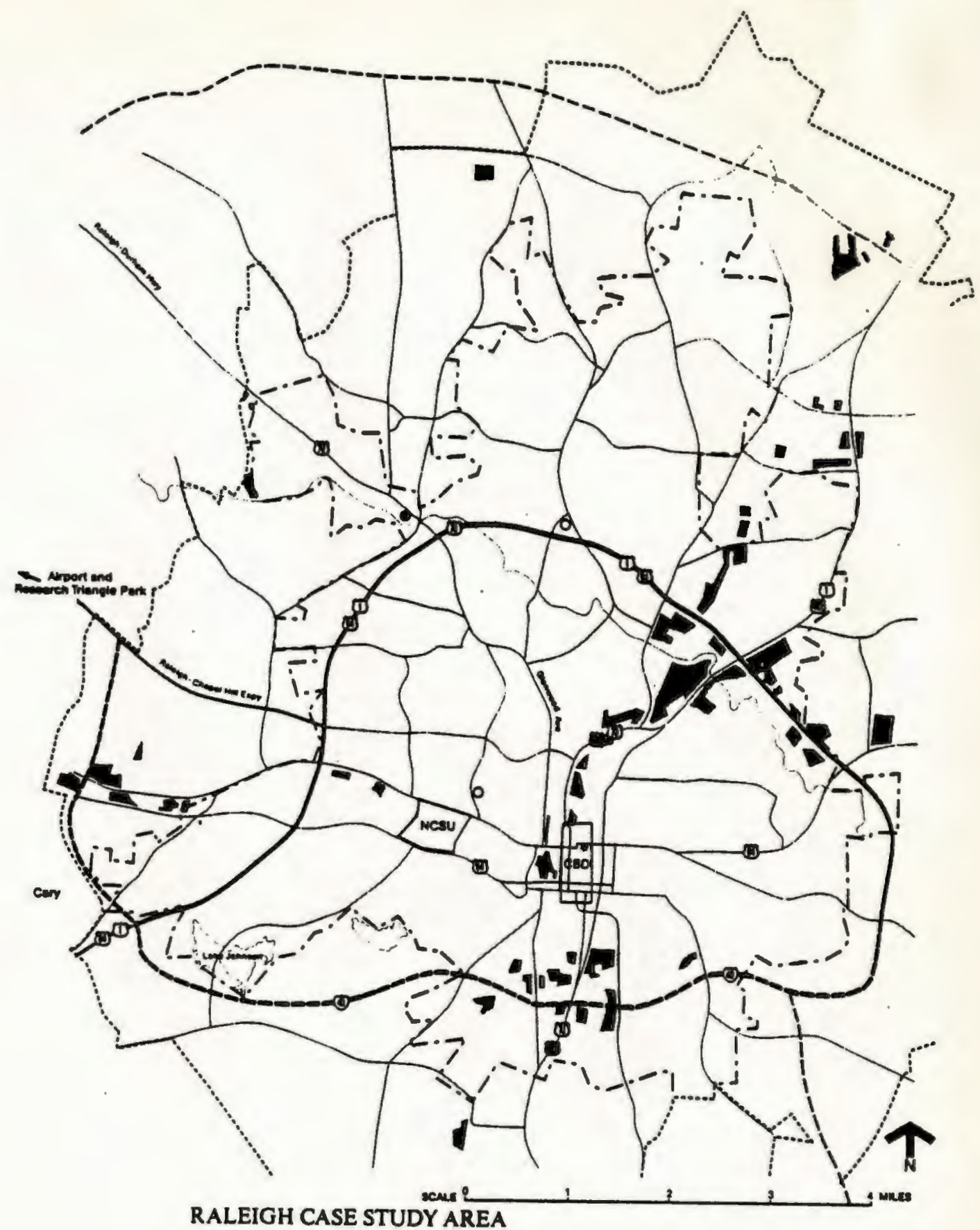

FIGURE V

\section{LEGEND}

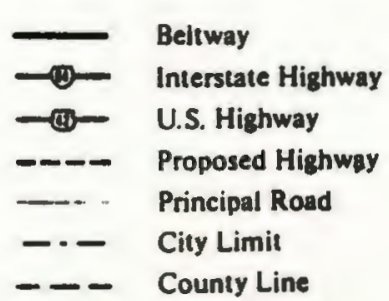

Shopping Center $>400,000$ Sq. Ft. Other Major Retail Center Industrial Park

cso Central Business District

(2) Airport 


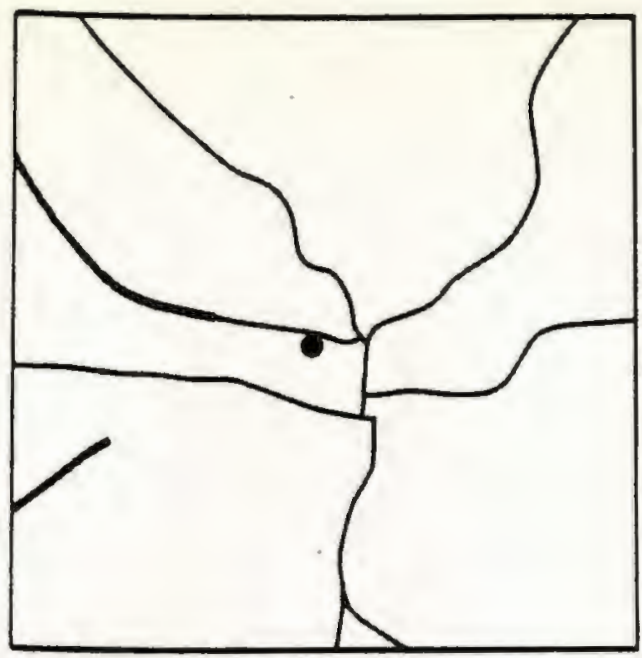

Pre 1957

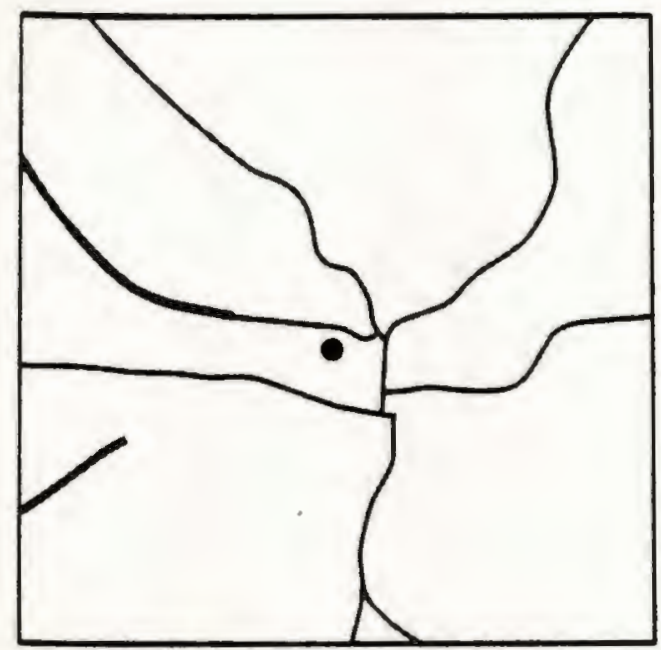

1961-1965

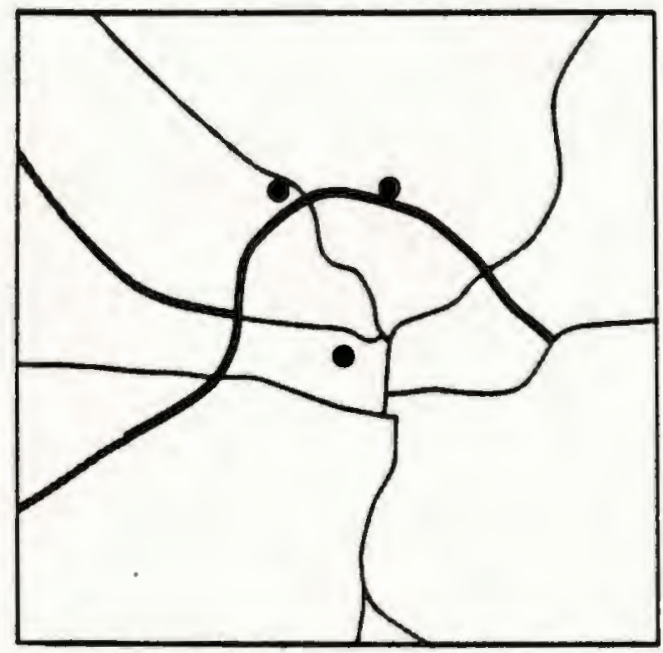

1971-1975

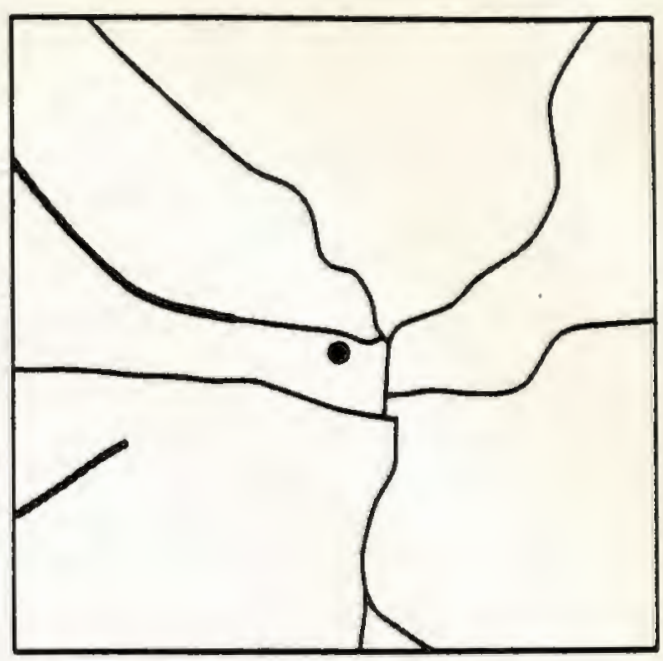

$1957-1960$

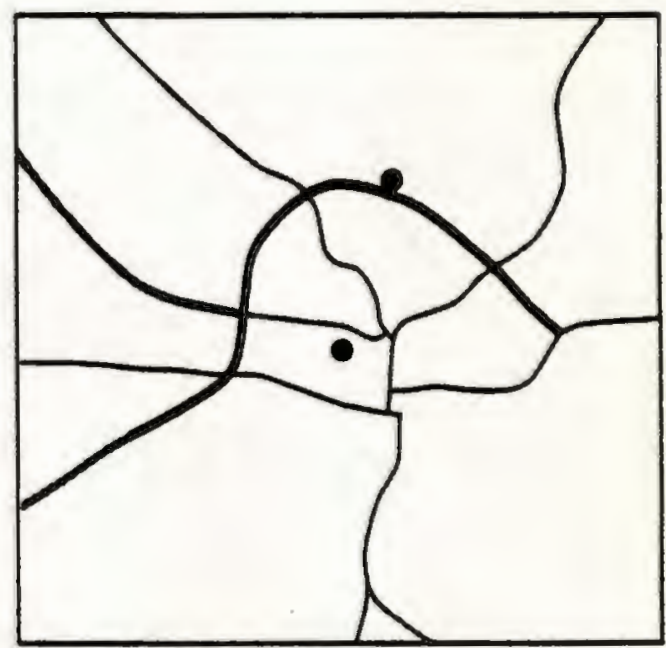

$1966-1970$

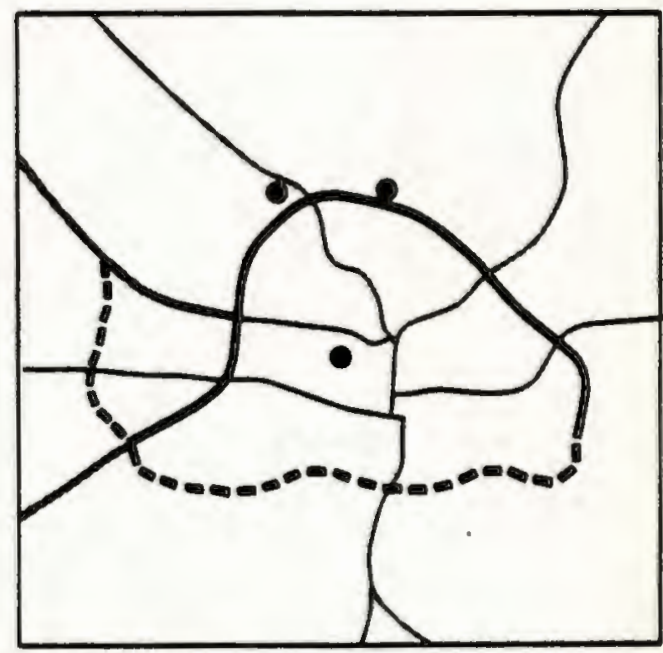

$1976-1980$

EVOLUTION OF THE RALEIGH BELTWAY

Base Map: 1979 Highway Network

- Regional Shopping Center 


\section{Demographics}

Trends indicate that Raleigh has a rapidly growing population, centralized in the city area. Between 1960 and 1970 the population increased 30.8 percent, and between 1970 and 1980 it increased 22.3 percent. (See Table $V$ ) The city has decreased in its share of Wake County and its SMSA population, but by a relatively small amount. This indicates a trend toward suburbanization, but not at the level of many other cities of comparable size. ${ }^{3}$

\section{Employment}

In 1979, over 25 percent of the work force in Raleigh was employed in the government sector, attributable to the city's function as state capitol. The services sector employed 21.6 percent of the work force and the wholesale and retail trade sector, over 19 percent. This is also due to the presence of three major universities in and near Raleigh. ${ }^{4}$ (See Table VI)

The Research Triangle Park, located between the city of Raleigh, Chapel Hill and Durham, employs more than 10,000, making it the largest planned research park in the United States. The majority of its employees live in Wake County and in Raleigh itself. 5 


\section{TABLE V}

POPULATION IN RALEIGH, WAKE COUNTY, AND SMSA, $1960-1980$

\begin{tabular}{|rrcccc|}
\hline Year & Raleigh & $\begin{array}{l}\text { Wake } \\
\text { County }\end{array}$ & \multicolumn{2}{c}{ City as $\%$} & \multicolumn{2}{c|}{ City as $\%$} \\
1960 & 93,931 & 169,082 & 56 & 323,998 & 29 \\
1970 & 122,830 & 229,006 & 54 & 419,254 & 29 \\
1980 & 150,255 & 301,327 & 50 & 531,167 & 28 \\
& & & & & \\
\hline
\end{tabular}

Sources: U.S. Department of Transportation, The Land Use and Urban Development Impacts of Beltways - Case Studies, 1980, p. R-3. 


\section{TABLE VI}

DISTRIBUTION OF NON-AGRICULTURAL EMPLOYMENT

IN RALEIGH SMSA BY SECTOR, 1979

\begin{tabular}{|lc|}
\hline Sector & Percent of Total \\
\hline Construction, Mining & 5.1 \\
Manufacturing & 16.9 \\
Transportation, Public Utilities, & 5.4 \\
and Communications & 19.6 \\
Wholesale and Retail Trade & 6.0 \\
Finance, Insurance, and & 21.6 \\
Retail Trade & 25.4 \\
Gervices & \\
\hline
\end{tabular}

Source: U.S. Department of Transportation, The Land Use and Urban Development Impacts of Beltways - Case Studies, 1980, p. R-4. 
Housing

Construction of the beltway around Raleigh had a significant impact upon multifamily housing during 1961 and 1972. After the plans for construction of a beltway were revealed, local developers began purchasing large blocks of land around the proposed right-of-way. Out of the approximate 3,400 apartment units built during this time, over half were oriented to the Beltline. While the belt had an affect on the clustering of multifamily units, the outward spread of single family housing had already begun to occur. Suburbanization of the area, therefore, cannot be totally attributed to beltway construction although it did provide a force for change. ${ }^{6}$

\section{Economic - Retail/Commercial}

The beltway has had a substantial impact on regional shopping in the Raleigh area. Two of the three regional shopping centers in the area are located at belt interchanges. Over 60 percent of the dollar cost of commercial development during 1961 to 1972 occurred within 4,000 feet of the beltway. ${ }^{7}$ (See Figure VI)

Retail sales within Raleigh's central business district declined from 1967 to 1977, while sales for the city as a whole have increased steadily. This is due to the fact that the beltway is located almost entirely within the city limits, and that it has attracted the location of two highly successful regional shopping centers. On the other hand, the beltway has been a major contributor to the Central Business District's loss of 
TABLE VII

RETAIL SALES TRENDS IN RALEIGH

$1967-1977$

\begin{tabular}{|lrrrrr|}
\hline & & & \multicolumn{2}{c|}{$\begin{array}{l}\text { Percent } \\
1967-\end{array}$} & $\begin{array}{l}\text { Change } \\
1972- \\
\text { Area }\end{array}$ \\
\hline Raleigh & 1967 & 1972 & 1977 & 1972 & 1977 \\
CBD & 258 & 455 & 673 & 76 & 48 \\
CBD as a & 76 & 68 & 46 & -11 & -32 \\
$\%$ of city & 29 & 15 & 7 & - & - \\
\hline
\end{tabular}

Source: U.S. Department of Transportation, The Land Use and Urban Development Impacts of Beltways - Case Studies, $1980, \mathrm{p} \cdot \mathrm{R}-16$ 
loss of sales. ${ }^{8}$ (See Table VII )

\section{Office}

Approximately 25 percent of the dollar value of new office space in Raleigh between 1961 and 1972 was constructed within 4,000 feet of a beltway interchange. The beltway, however, has not had a substantial negative effect on new office construction within the Central Business District, which has increased its regional share. ${ }^{9}$ Over 50 percent of the total amount of new office space constructed between 1961 and 1972 was built within one mile of a beltway interchange. The belt has had a clear effect upon the new office space locations. However, the city is continuing to attract office development to meet the needs of the government sector.

\section{Industry}

During the years 1961 to 1972 nearly 50 percent of the dollar value of new industrial development occurred within 4,000 feet of a beltway interchange. Much of the recent industrial development has taken place north of U. S. 1 , and has not been relocated from the Central Business District.

Summary

The Raleigh Beltline has had a positve impact upon the city, with the most improvement coming in the areas of office space, retail and commercial establishments, and in improving the general accessibility of the region. Not only does the 
road provide a loop around the central city, but it also forms an important link in the region's crosstown traffic network. Through this function it has satisfied the reasons for its construction, traffic congestion relief. 10

The belt forms an important access link for the employees of the Research Triangle Park, most of whom live in the Raleigh area.

Construction of the Beltline seems to have stimulated a change in the character of the central city. During the years between 1960 and 1970 the bulk of new development occurred around the belt. This removed the retail character of the city to some extent, and it is now viewed as a governmental, administrative, financial and entertainment center. Recently this change in character has reverted somewhat, with the construction of a civic center complex and a new downtown mall.

There are no significant negative impacts that the beltway has had upon the central city. ${ }^{11}$ Rather than act as an outward pull, removing life from the city, it has brought in new firms and establishments, provided improved access to the city, and generally acted as a strong base on which to build the central city. 


\section{FOOTNOTES}

1. U.S. Department of Transportation, The Land Use and Urban Development Impacts of Beltways - Case Studies, (U.S. Government Printing Office, Washington, D.C., i980) p. R-1.

2. Ibid., p. R-2.

3. Ibid., p. R-3.

4. North Carolina State in Raleigh, Duke University in Durham, and the University of North Carolina at Chapel Hill.

5. U.S. Dept. of Transportation, p. R-3.

6. Ibid., p. R-4.

7. Ibid., P. R-13.

8. Ibid., p. R-13.

9. Ibid., p. R-17.

10. Ibid.

11. Ibid., P. R-18. 


\section{APPENDIX II}

R.I. INDUSTRIAL PARKS BY MUNICIPALITY ${ }^{1}$

Cranston

Howard Industrial Park

I-95 and Rte. 37

190 Acres: 124 Available

Pettaconsett Industrial Park

I-9.5 and Rte. 37

32.6 Acres: None Available

Western Cranston Industrial Park

Comstock Parkway and I-295

100 Acres: 100 Available

Cumberland

Cumberland Industrial Park

30 Acres: 22 Available

\section{Lincoln}

Lincoln Park for Office and Industry

Albion Road

60 Acres: None Available

North Central Industrial Air Park

Albion Road and Powder Hill Road

250 Acres: None Available

North Central/295 Industrial Park

Washington Highway

84 Acres: 55 Available

Smithfield

Interchange Realty

Rte. 44 and I-295

116 Acres: 116 Available

Lan-Rex Industrial Park

Farnum Pike

!2 Acres Available

Lark Industrial Park

Lark Industiral Parkway

42 Acres: 19 Available

1. Those in the corridor region and Providence only. 
Smithfield cont.

Puritan Site

Rte. 7 and I-295

30 Acres: 30 Available

Smithfield Industrial Park

Rte. I-295 and Rte. 116

45 Acres: 27 Available

295 Industrial Park and Office Park

Rte. 7 and I-295

65 Acres: 50 Available 


\section{SOURCES}

Bishop, A. Bruce, C.H. Oglesby, and Gene E. Willeke. Socio-Economic and Community Factors in Planning Urban Freeways Washington, D.C.: U.S. Dept. of Transporation 1970.

Bone, A.J. Route 128 Study: Survey of Industrial Development Boston, Mass.: Mass. Division of Public Works 1958.

Boston Redevelopment Authority. Transportation Facts for the Boston Region, 1967 Boston, Mass.: Boston Redevelopment Authority 1967.

Boston Redevelopment Authority. Transportation Facts for the Boston Region, 1968-69, Boston, Mass.: Boston Redevelopment Authority 1969.

Chudacoff, Howard P. The Evolution of American Urban Society Englewood Cliffs, New Jersy: Prentice Hal1 1981.

deNeufville, Judith. Social Indicators and Public Policy New York: Elsevier Publishing Co. 1975.

Frederiksen, Robert C. "\$5.3 million approved for work on Route 295" Providence Journal-Bulletin Nov. 10, 1978.

Governor's Highway Study Committee. Rhode Island RoadsA Report on Highway Problems Providence, R.I.: Herald Press 1958.

Hammerschlag, Dieter. The Interstate Highway System and Urban Structure: A Force for Change in Rhode Island Providence, R.I.: R.I. Dept. of Transportation 1976.

Harrington, Vincent $K$. "Industrial Parks in Rhode Island" Providence, R.I.: R.I. Dept. of Economic Development 1982 .

Interview with Ted Green, Executive Director, Capital Center Commission, Providence, Rhode Island, April $18,1983$. 
Interview with Susan Morrison, R.I. Statewide Planning

Program, Providence, Rhode Island, April 12, 1983.

Interview with Ken Orenstein, Providence Foundation, Providence, Rhode Island, April 15, 1983.

Interview with Marcel Valois, Blackstone Valley Chamber of Commerce, Pawtucket, Rhode Island, April $11,1983$.

Kelly, Paul A. "Rolling out Route 295 carpet (maybe, probably, hopefully)" Providence JournalBulletin, February 16, 1975.

Kelly, Paul A. "Route 295 main lanes open today, 10 years after forecast date" Providence Journa1Bulletin, June 12, 1975.

Kelly, Paul A. "Route 295 opening is eyed" Providence Journal-Bulletin, Apri1 15, 1975.

Krupa, Gregg. title unknown. Providence JournalBulletin, Nov. 10, 1981, p. F-1.

Land, Kenneth C. Social Indicator Models New York: Sage Foundation 1975.

Levitan, Don. "Highway Development and Local Government: An Analysis of Relationships - A Case Study of Massachusetts Route 128" Thesis New York University 1971.

Little, Arthur D., Inc. Industrial Development and Highway Planning in Rhode Island Cambridge, Mass.: Arthur D. Little, Inc. 1959.

MacConnel1, William P. Remote Sensing Land Use and Vegetative Cover in Rhode Island Kingston, Rhode Island: University of Rhode Island Cooperative Extension Service 1974.

Maguire, Charles A. and Associates. Basic Study Report Interstate Route 295: Warwick, West Warwick, Cranston, Johnston, and Smithfield Boston, Mass.: Charles A. Maguire and Associates 1959. 
Massachusetts Department of Commerce and Development. The Golden Semi-Circle Boston, Mass.: Massachusetts Dept. of Commerce and Development 1974.

Massachusetts Division of Employment Security. Annual Planning Information Report - Fiscal Year 1983 Greater Boston Boston, Mass.: Massachusetts Division of Employment Security 1983.

Mills, Florence. "Effects of Beltways on the Location of Residences and Selected Workplaces," Transportation Research Record No. 812, Washington, D.C.: National Acadeny of Sciences 1981.

Muller, Thomas, et al. The Impact of Beltways on Central Business Districts: A Case Study of Richmond Washington, D.C.: The Urban Institute 1978 .

Providence Journal-Bulletin. A Guide to Rhode Island Shopping Centers Providence, Rhode Island: Providence Journal-Bulletin 1981.

R.I. Department of Community Affairs. Major Industrial Sites on Interstate 295 in Rhode Island Providence, Rhode Island: R.I. Development Council 1970.

R.I. Department of Economic Development. Rhode Island Basic Economic Statistics 1982-83 Providence, Rhode Island 1983.

R.I. Department of Economic Development. Rhode Island Basic Economic Statistics, 1977-78 Providence, Rhode Island: R.I. Dept. of Economic Development 1978 .

R.I. Department of Economic Development. Rhode Island Basic Economic Statistics, 1968 Providence, Rhode Island: R.I. Development Council 1968.

R.I. Department of Economic Development. "Rhode Island 1980 Census Data - Selected Tables by County, City and Town" Providence, Rhode Island: R.I. Dept. of Economic Development 1982.

R.I. Department of Transportation. "Traffic Flow Map : 1981. 
R.I. Statewide Planning Program. Land Zoned for Industrial Use: Inventory and Analysis Technical Paper No. 76. Providence, Rhode Island: R.I. Statewide Planning Program 1978.

Skidmore, Owings and Merill. Capital Center Design and Development Criteria Providence, Rhode Island: Skidmore, Owings and Merrill 1980.

U.S. Department of Commerce. U.S. Census of Population and Housing: 1960 Washington, D.C.: U.S. Government Printing office 1961.

U.S. Department of Commerce. U.S. Census of Population and Housing: 1970 Washington, D.C.: U.S. Government Printing Office 1971.

U.S. Department of Commerce. U.S. Census of Population and Housing: 1980 Washington, D.C.: U.S. Government Printing office 1981.

U.S. Department of Transportation. Social and Economic Effects of Highways Washington, D.C.: U.S. Dept. of Transportation 1974.

U.S. Department of Transportation. Social and Economic Effects of Highways Washington, D.C.: U.S. Dept. of Transportation, 1976.

U.S. Department of Transportation. The Land Use and Urban Development Impacts of Beltways Washington D.C.: U.S. Government Printing office, 1980 .

U.S. Department of Transportation. Radial Freeways and the Growth of Office Space in the Central Cities Washington, D.C.: U.S. Dept. of Transportation 1977.

U.S. Geological Survey. Selected quadrangle maps. $1970,1975$. 